\title{
Surface Modified Techniques and Emerging Functional Coating of Dental Implants
}

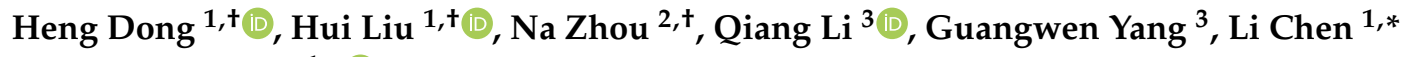 \\ and Yongbin Mou ${ }^{1, *(\mathbb{D})}$ \\ 1 Department of Oral Implantology, Nanjing Stomatological Hospital, Medical School of Nanjing University, \\ Nanjing 210008, China; dongheng90@smail.nju.edu.cn (H.D.); margaret1992peggy@163.com (H.L.) \\ 2 Department of Jiangbei, Nanjing Stomatological Hospital, Medical School of Nanjing University, \\ Nanjing 210008, China; zhounanju@foxmail.com \\ 3 Central Laboratory, Nanjing Stomatological Hospital, Medical School of Nanjing University, \\ Nanjing 210008, China; hnliqiang@foxmail.com (Q.L.); ygw_guangwenyang@163.com (G.Y.) \\ * Correspondence: lichentree@smail.nju.edu.cn (L.C.); yongbinmou@163.com (Y.M.) \\ + These authors contributed equally to this study.
}

Received: 23 September 2020; Accepted: 20 October 2020; Published: 22 October 2020

\begin{abstract}
Dental implants are widely used in the field of oral restoration, but there are still problems leading to implant failures in clinical application, such as failed osseointegration, marginal bone resorption, and peri-implantitis, which restrict the success rate of dental implants and patient satisfaction. Poor osseointegration and bacterial infection are the most essential reasons resulting in implant failure. To improve the clinical outcomes of implants, many scholars devoted to modifying the surface of implants, especially to preparing different physical and chemical modifications to improve the osseointegration between alveolar bone and implant surface. Besides, the bioactive-coatings to promote the adhesion and colonization of ossteointegration-related proteins and cells also aim to improve the osseointegration. Meanwhile, improving the anti-bacterial performance of the implant surface can obstruct the adhesion and activity of bacteria, avoiding the occurrence of inflammation related to implants. Therefore, this review comprehensively investigates and summarizes the modifying or coating methods of implant surfaces, and analyzes the ossteointegration ability and anti-bacterial characteristics of emerging functional coatings in published references.
\end{abstract}

Keywords: dentistry; dental implants; surface modified; osseointegration; bacterial antagonist; functional coatings; active surfaces; coating performance

\section{Introduction}

Dental implants have been proven to have predictable and reliable therapeutic effects for repairing lost teeth [1-3]. Although dental implantation has a high success rate and survival rate, it is still difficult to avoid implant failures due to some risk factors [4]. Many reasons would result in failed dental implants, including implant-, clinician-, and patient-related factors, infection, and foreign body reactions, which may accelerate alveolar bone loss [5]. The loss of alveolar bone, usually accompanied by the accumulation of microbial plaque and bacterial infections and is primarily associated with peri-implantitis, is the chief cause for implant failures [6]. As a result, maintaining stable ossteointegration and avoiding bacteria-related alveolar bone loss are of great significance in dental implantation. Ideal ossteointegration is ensured by direct, structural and functional contact between bone tissues and the surface of an implant loading occlusal force [7]. The productive osseointegration is crucial to maintain long-term stability between implants and newly-formed peri-implant bone, which helps to shield implants from soft tissues [8]. 
Dentists designed implants with different sizes, lengths, shapes, threads, and surface treatments to deal with different alveolar bone conditions in the field of implantology in the past 50 years [9]. The implant surface design creates a safe side to prevent most of the oral bacteria, and even have a sterilizing effect, and an optimized surface of implants has been attached more and more important to among those designs in an optimal process of osseointegration. As early as the 1990s, Buser et al. firstly compared the influences of surface characteristics on bone ossteointegration among 5 different surfaces of titanium in a preclinical study [10]. So far, many scholars have devoted to promoting the engineering designs of implant surface, in order to optimize titanium implant-related osseointegration by improving a series of physiological reactions such as attachment, proliferation, differentiation, matrix synthesis and calcification of osteoblasts in the peri-implant alveolar bone [11]. Currently, the zirconia implants have received widespread attention to white-colored surfaces, which are considered esthetically superior to the gray-colored titanium [12]. However, non-metallic surfaces require some special modification methods to promote osseointegration. Generally, modifying the properties of implant surface, for instance, roughness, free surface energy, and chemical composition, is an effective method to achieve fast healing and better osseointegration [13]. Also, micro-nano structural modification of the implant surface, which could enhance the hydrophilicity and bone conductivity of the implant, and reduce the stress conduction, is a research hotspot in the field of implantology. Additionally, various methods of surface coatings to enhance the biological activity of implant surface, which mostly are involved in interdisciplinary fields of biology and materials, are rapidly developing. These methods could optimize the implant surface features, including the chemical composition, charge, wettability, and roughness of surfaces, and can finally affect the interaction with bacteria [14]. Active molecules grafting onto the implant surface is the most representative and potential modification method, which could reduce foreign body reaction (FBR) and improve osseointegration in some preclinical researches [15]. Nonetheless, how to avoid the inactivation of these active molecules in body fluids is a thorny problem in translational research. Therefore, in order to reduce the incidence of peri-implantitis, it is necessary to exploit the advanced implant surface coatings, which could both enhance the osseointegration process, as well as prevent or inhibit bacterial colonization.

In this review, we recapitulated the existing surface modification technologies of mainstream dental implants, and elucidated the correlation between implant surface coatings and their performance of osseointegration or anti-bacterial ability (Figure 1). Meanwhile, we described the most promising developments of functional coatings in recent decades.

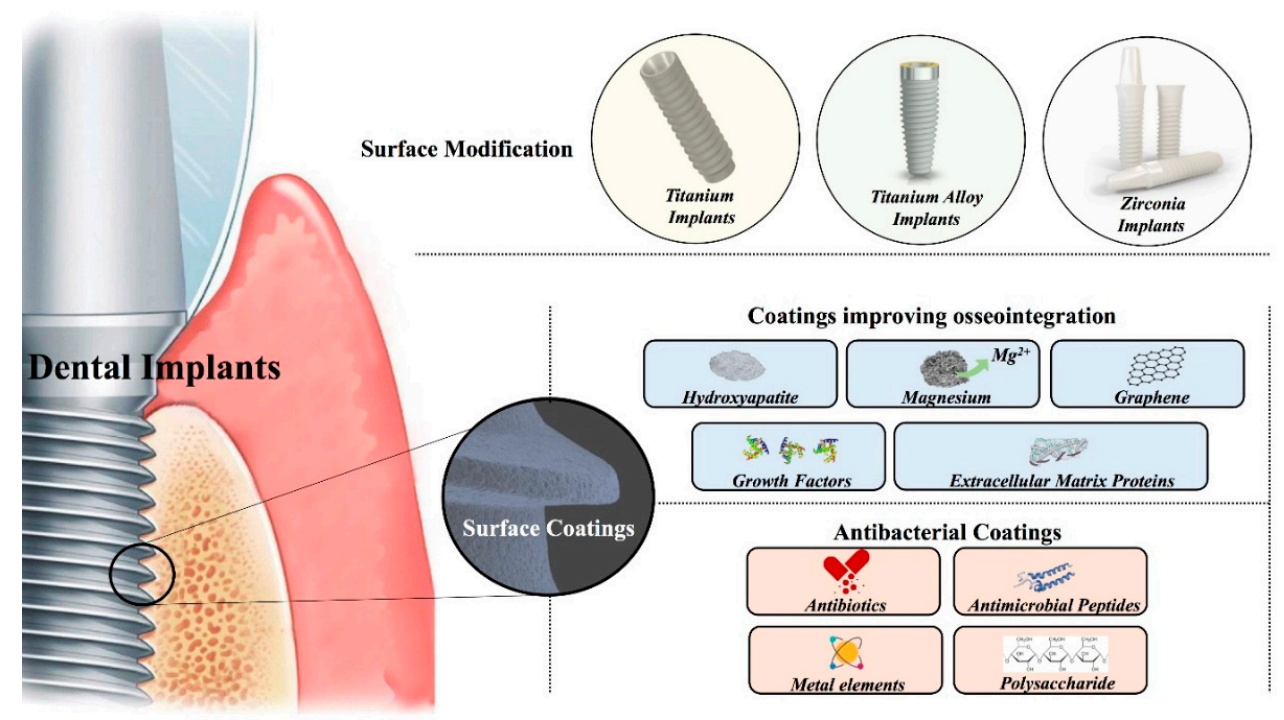

Figure 1. A schematic illustration of Surface Modifies and Functional Coating of Dental Implants. 


\section{Surface Modification Technologies of Dental Implants}

\subsection{Surface Modifications of Titanium-Based Implants}

The properties of titanium met most of the dentistry requirements, including corrosion resistance, excellent biocompatibility, relatively high strength, low modulus of elasticity, favorable machinability, and formability. By altering or modifying the surface texture to get the roughness of titanium implants, desired effects could be obtained, such as better bone-to-implant contact (BIC) and removal torque values [16].

\subsubsection{Physical Modifications of Titanium Implants}

Titanium implants are still the most commonly used in implantology, due to their excellent biocompatibility and superior ability to gain osseointegration. Usually, the osseointegration rate between living bone and titanium surface is associated with the composition and surface roughness [17]. The original machined Brånemark implant had a nearly smooth surface (0.5-1.0 $\mu \mathrm{m}$ average roughness), but it has been proven that rough-surfaced titanium implants have a higher percentage of BIC rate than those with the smooth surface [18]. The rough-surface increases BIC and enhances the removal torque forces, which makes for initial and long-term stability of dental implants [19]. Physical modification could change the surface morphology and roughness of most titanium implants, which is beneficial to the process of osseointegration. A sandblasting technique is the most commonly used physical method for modifying the surface. It would create microroughness under proper pressure to the implant surface with an airstream of accelerated particles, such as titanium dioxide $\left(\mathrm{TiO}_{2}\right)$, aluminum oxide $\left(\mathrm{Al}_{2} \mathrm{O}_{3}\right)$, silicon dioxide $\left(\mathrm{SiO}_{2}\right)$, or hydroxyapatite (HA) powders. Moreover, the capacity of osseointegration in these groups did not show significant differences [20,21]. This modification method prepared the titanium surface with the advantages of both topography and wettability, resulting in higher cell attachment, cell proliferation, and differentiation properties of osteoblast cells [22]. The textured titanium implant surface was constructed by traditionally machined blasting with calcium phosphate ceramic, then passivated to remove residual media without acid etching. It was found that the titanium implants treated with absorbable sandblasting media had a higher overall success rate and showed no apparent marginal bone loss in a 4-year clinical observation study [23].

In addition to sandblasting, there are some other physically modified technologies, such as plasma spraying, magnetron co-sputtering, wire electrical discharge machining, thermal treatment, laser surface modification, and Ultraviolet (UV) irradiation. Porous titanium surfaces deposited by atmospheric plasma spraying techniques can also increase surface roughness. However, this technique tends to form a relatively thick oxide layer on the surface; once this layer is too thick for tissue adhesion, normal osteogenesis process would be slowed down [24]. It was reported that acid-etching could increase roughness and decrease the thickness of the oxide layer prepared by atmospheric plasma spraying, which possibly contributed to osseointegration [25]. The wire electrical discharge machining could create sub-surface interconnectivity of intersecting and high-aspect-ratio pores on implant surface, which were usually with 180-250 $\mu$ m diameter. Compared with simpler surface geometries, these pore-morphologies enhanced osteogenesis, produced higher bone-to-implant interface strengths, and showed lower susceptibility to stress shielding of surrounding bone [26,27]. Hydro-thermal modifying meant that titanium was thermally treated in atmospheric pressure or peroxide, which can form a dense oxide film on the surface and increased biocompatibility [28]. This technology is also expected to make titanium nitride with outstanding abrasion resistance and favorable soft tissue affinity [29]. The neodymium-doped yttrium aluminium garnet laser (Nd:YAG laser) was one of the most commonly used lasers in the treatment or processing of titanium implants, which enabled the laser-modified titanium implants to promote osteoblast-like cells attachment and proliferation [30]. UV irradiation was also a method to promote the osseointegration performance of titanium implants [31]. During the early healing period, the implants treated by Ultraviolet- $C$ irradiation inspired the potential to improve the amount of bone growth [32]. The above physical methods can change the surface morphology and roughness of implants and provide a better basis for osseointegration. 


\subsubsection{Chemical Treatments}

Surface chemical modification refers to changing the structure and state of implant surface through chemical adsorption or reaction between titanium surface and the surface modifier [33]. Anodization is one of the most commonly used chemical modified techniques to construct microtopographies, which is based on a potentiostatic or galvanostatic electrochemical oxidation of titanium surface using strong acids, including $\mathrm{H}_{2} \mathrm{SO}_{4}, \mathrm{H}_{3} \mathrm{PO}_{4}, \mathrm{HNO}_{3}, \mathrm{HF}$, and so on. This technology would produce a thick porous layer of titanium oxide on the surface, which may stabilize the very thin and compact native oxide layer on the implant surface [34]. The strong acids mentioned above could also be used in acid-etching methodology, which will create micro-roughness by forming microwells on the titanium implant surface. Dual acid-etched (DAE) implant surface has shown improved histological performance, histomorphometric bone response, and higher removal torque values compared with machined (MA) dental implants in clinic [35]. Except for those technologies, the alkali-heat treatment technology can prepare well-organized nanotopographic titanium surface with nanospikes and pores, which could promote gingival fibroblastic collagen synthesis and the regeneration of periodontal-like connective tissue attachment with substantial detachment resistance [36]. Micro-arc oxidation can form a nano-bioactive titanium oxide layer, improving the adhesion of implants and enhancing cell adhesion [37]. The two-phase hydroxyapatite titanium dioxide modifying prepared by plasma electrolytic oxidation shows both the biological activity of the hydroxyapatite modifying and the advantages of the improved surface morphology of titanium dioxide, which can effectively promote bone bonding [38]. Currently, these chemical surface treatment technologies are seldom solely used. Instead, a combination of multiple treatment methods will achieve more optimized clinical effects.

\subsubsection{Multi-Step Modified Methodologies}

The sandblasting and acid etching appears to be a safe method that produces reliable and predictable surfaces of titanium implant surface [39]. The SLA (Sandblasted/Large-grit/Acid-etched) treatment has been widely applied in modifying surfaces for dental titanium implants. The SLA technology increased the roughness of the implant surface by acid etching after large-particle blasting. It could form a textured surface possibly recognized by fibroblasts, which has been proven to induce a rapid and strong implant fixation [40]. The SLA treatment has also been reported as a prospective technique to increase wettability and surface energy, which positively contributes to the osseointegration at an early stage [41]. Aiming to enhance the hydrophilicity and biological activity, the chemically modified SLA surfaces (SLActive) based on SLA surfaces were made via rinsing under nitrogen protection and being stored in an isotonic salt solution following the same preparation procedure as SLA [42]. In general, SLActive micro-rough surfaces show a stronger cell and bone tissue response than SLA surfaces. However, this difference may disappear after 6-8 weeks [43].

Besides, the double-modifying technology prepares a surface with unique layered micro-morphology. First, the micro-arc oxidation is performed on the titanium surface, and then the surface is electrochemically reduced in an alkaline solution. The results showed that the cell proliferation and bone formation rate around the implant increased, as well as the bone-to-implant contact area and cell adhesion [44]. The individual chemical surface properties of the titanium implant surface affect bone-bonding. The self-assembled monolayer-technique can be used to couple multiple functional groups and biological agents on surfaces of titanium. The tailored surface chemistry on the titanium surface is constructed by a self-assembled monolayer modified technique and subsequent immobilization of biological agents [45]. This layer-by-layer self-assembly method can also potentially modify Ti surfaces with specific small interfering RNA to accumulate the multilayered film on smooth titanium surfaces and enhance bio-function [46].

A biochemical approach modifying implant surface may offer a multi-step method, which may stimulate bone formation adjacent to the surface of implants inserted into the bone. The biomimetic advanced surface topography is obtained through shot blasting and anodizing procedure, which simultaneously produce macroroughness, microporosity of titanium oxide, and deposition of 
calcium/phosphate ion. This surface promotes the up-expression of osteoblastic differentiation markers and improves substantial osteoinduction [47]. The biofunctionalized composite modifier is created on nanopolymorphic Ti surfaces by alkali and heat $(\mathrm{AH})$ treatment, then adsorbing the positively charged protamine/alginate/protamine, modifying and further immobilizing the exogenous bone morphogenic protein-2 (BMP-2) to promote the osseointegration [48].

The multi-step modification method, which is based on the surface of the Ti-based implants, focuses on improving the bone-to-implant osseointegration and reducing bacterial adhesion on the surface of the titanium implant. However, it still needs to develop and optimize more surface modification methods.

\subsubsection{Surface Microstructure and Topography of Commercially Titanium Implants}

Different manufacturing techniques will form different titanium implants in terms of surface microstructure and topography. The four parameters were used to describe the numerical value of surface topography, including the arithmetic mean of the roughness area from the mean plane (Sa), the ratio between the developed surface area and a flat reference area (Sdr), the density of summits (Sds), and core fluid retention index (Sci). The topographic modifications can generate surfaces that can be classified as a function of their roughness (Sa) in smooth surfaces (Sa $=0-0.5 \mu \mathrm{m}$ ), minimally rough $(\mathrm{Sa}=0.5-1 \mu \mathrm{m})$, moderately rough $(\mathrm{SA}=1-2 \mu \mathrm{m})$, or rough surfaces $(\mathrm{Sa}>2 \mu \mathrm{m})$ [49]. The nanometer structures of the implant surface are essential for molecules to attach, which may affect the initial stages of osseointegration and promote cellular response on nanostructured surfaces. Numerous researches demonstrate that the surface roughness of Ti implants influences bone healing and biomechanical fixation. The surface roughness can be divided into macro-, micro- and nano-sized topologies, according to the scale of the features [50]. There are significant differences in mean Sa on a nanometer level were shown among commercially available implants investigated (Figure 2) [51]. How these micrometer and nanometer structures possibly influence early bone response and the osseointegration in vivo is of great interest to dentists.
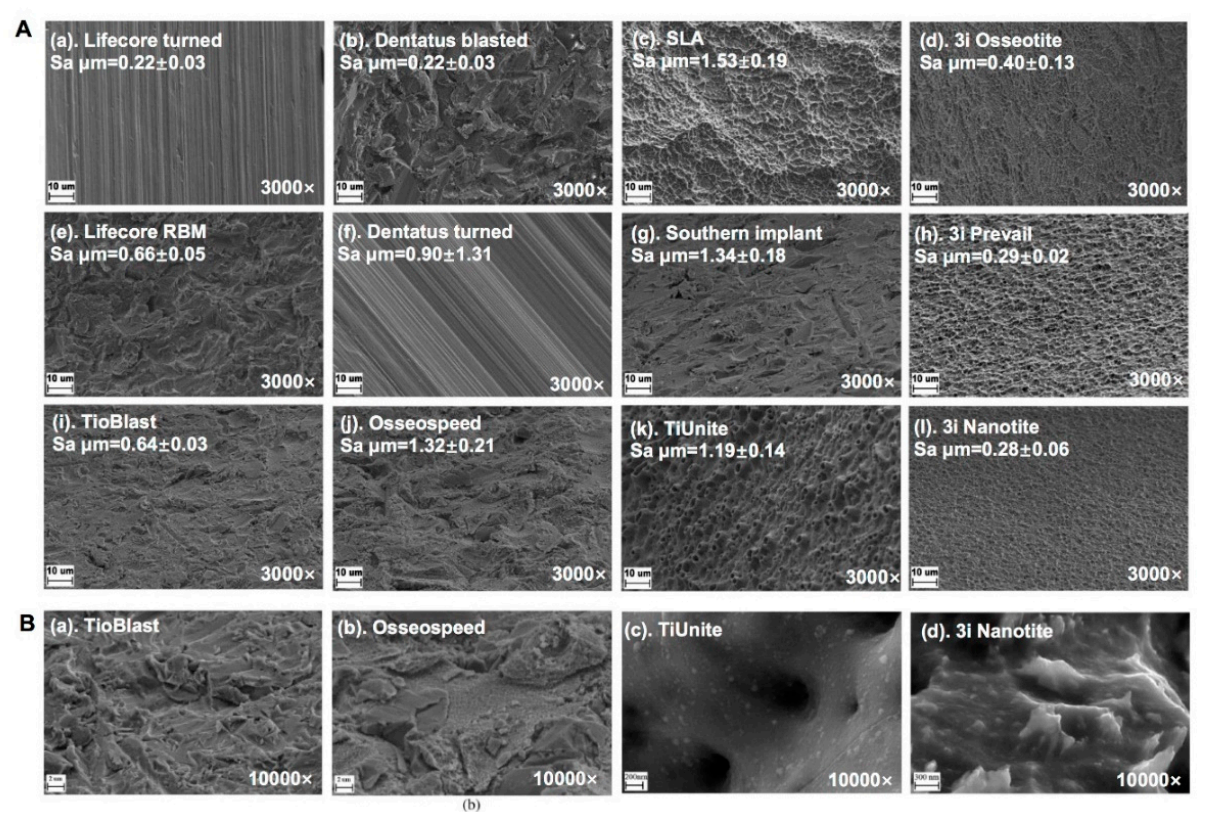

Figure 2. Scanning electron microscopy (SEM) images on the Variety Commercially Available Titanium Implants. (A) At a magnification of 3000x, the images show a homogenous honeycomb-like structure for the etched implants, SLA, and $3 \mathrm{i}$ implants. The blasted implants, TioBlast, Osseospeed, Southern implant, Lifecore RBM and Dentatus blasted, had a similar mountain-like structure. (B) At a magnification of $10,000 \times$, a honeycomb-like structure, similar to the one found on etched implants, was found partly on the Osseospeed implant. Nanosized structures were detected on the TiUnite and 3i Nanotite surfaces [51]. Copyright 2010 Wiley Periodicals, Inc. 


\subsection{Titanium Alloy Implants Surface Modifications}

The concept of narrow-diameter implants was proposed to solve the dilemma of compromised esthetics outcomes of patients with insufficient bone volume and limited interdental space [52]. Diameter-reduced titanium alloy implants, such as titanium-6aluminum-4vanadium (Ti-6Al-4V), titanium-zirconium (TiZr), and Ti-13Nb-13Zr (wt.\%, hereafter denoted $\mathrm{Ti}-\mathrm{Nb}-\mathrm{Zr}$ ), have improved their mechanical strength due to excellent mechanical and biological compatibilities [53,54]. The chemical and physical properties of implant surface may affect the structure of the bone-to-implant surface and affect the therapeutic efficacy. Some surface modifications are utilized to improve wear resistance or osseointegration of titanium alloy implants, such as SLA, thermal treatment, ion implantation, physical vapor deposition modifies [55]. Also, laser surface melting of Ti-6Al-4V was implemented via $\mathrm{a} \mathrm{CO}_{2}$ laser, and the surface can preferentially enhance cell adherence, proliferation, and bioactivity to promote the osseointegration [56]. In the periodic table, titanium and zirconium are the same group transition elements with similar chemical properties. Titanium zirconium alloy with 13-17\% zirconium (Ti-Zr1317) is an alloy with a monophasic $\alpha$-structure, thus Ti-Zr1317 and pure titanium implants can construct a topographically identical surface by SLA surface treatment. Meanwhile, Ti-Zr1317 displays significantly better elongation and fatigue strength than pure titanium. Jan et al. verified the Ti-Zr1317 implant with a hydrophilic SLA surface showed similar or even stronger bone tissue responses than the Ti control implant (Figure 3) [57]. TiZr implant, with a $15 \%$ zirconium content ( $\alpha$-structure) and SLActive modified hydrophilic surface, showed faster osseointegration and significantly less multinucleated giant cells surface adherence than Ti-6Al-4V implants after 4 and 8 weeks [58]. The SLActive surface enhanced surface wettability and influences the adsorption of inorganic matter, proteins, lipoproteins, peptides, as well as the fibrin network onto the hydroxylated/hydrated groups, which shorten the healing period to a great extent. In addition to SLA, TiZr could be modified via a high voltage anodization process, which would form a dense and uniform oxide layer with a crystalline, nano-to-micro porous, hydrophilic surface. The anodized TiZr surfaces with nano-pores can potentially modulate the osteoblast cell behavior promoting more rapid bone formation rather than anodized Ti [59].
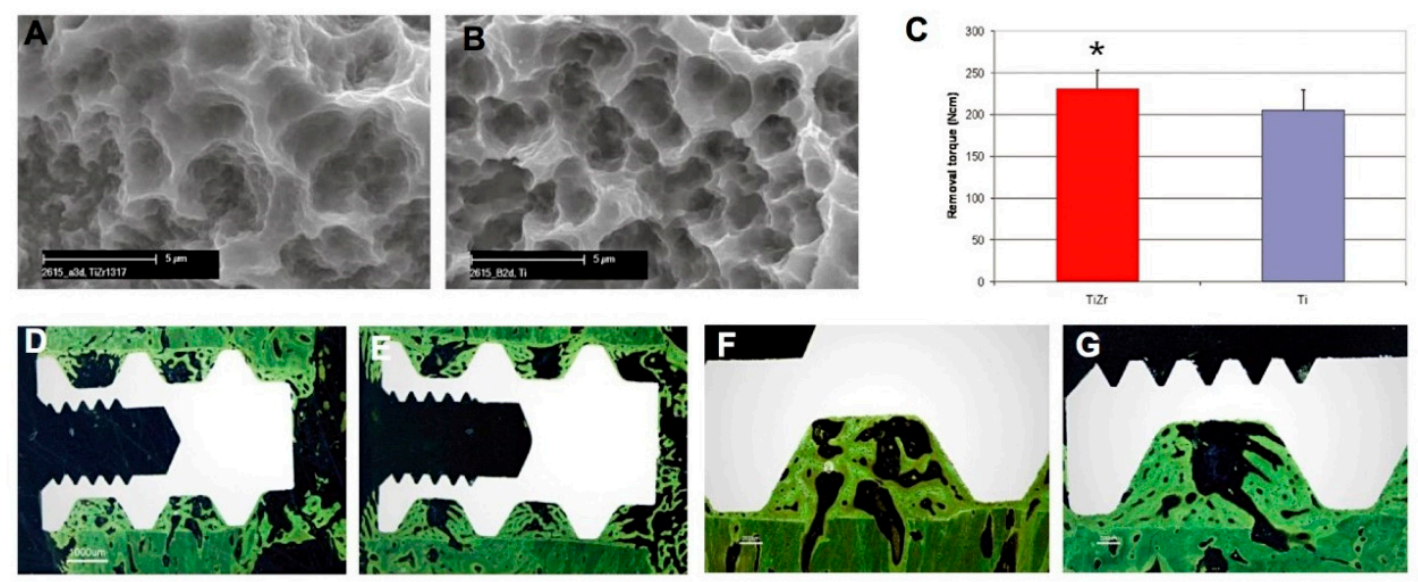

Figure 3. The comparison between and Ti-Zr1317 and Ti implant surfaces.SEM images of (A) Ti-Zr1317 and (B) Ti surfaces. (C) The Ti-Zr1317 implants showed a significantly higher mean value of peak removal torque test than Ti implants $(* p<0.05)$. Light micrographs in inverted colors of bone chamber implants in (D,F) a Ti-Zr1317 specimen and (E,G) a Ti specimen [57]. Copyright 2012 Wiley Periodicals, Inc.

The oxide layer of the implant surface possesses corrosion resistance performance. Once it breaks down the implant vulnerable to corrosion, it can induce an allergic reaction [60]. Titanium alloys can resist corrosion in vivo to a great extent. Many methods, such as the plasma-assisted physical vapor deposition (PVD) technique, thermal oxidation (TO) method, polymer-assisted deposition (PAD) technique, and laser metal deposition (LMD) process, could promote the corrosion characteristics of titanium alloys [61-64]. In addition, the high coefficient of friction and low surface hardness of 
titanium alloys favor low wear resistance. Thus, some surface modifications, like thermal oxidation treatment, ion implantation, and physical vapor deposition, are utilized to increase the wear resistance of the titanium alloy implants $[65,66]$. The different techniques above followed by proper surface modifications are applied to obtain the required properties of titanium alloy implants.

\subsection{Zirconia Implant Surface Modifications}

In the last decade, zirconia has recently been introduced to implant dentistry due to its white color meeting the increasingly heightened esthetic demand and its excellent properties, such as low modulus of elasticity and thermal conductivity, and high biocompatibility [67]. The mechanical stability of zirconia can also be improved by the addition of tetragonal polycrystals of yttrium [68]. Although the previous literature has reported a similar bone healing process for zirconia-based or titanium-based implant surfaces, some controversies towards osseointegration of zirconia implant are still being argued because of a lack of long-term clinical researches [69]. However, higher organization of collagen fibers and lower sulcus depth in gingival tissue are observed around zirconia implants than titanium, which can potentially increase soft tissue integration (Figure 4) and further improve the aesthetic results of the implantation. Although the surface was roughened by the ZiUnite ${ }^{\mathrm{TM}}$ surface technology and exhibited a proprietary porous surface modification, Kohal et al. have considered that the zirconia implant resulted in high failure rates and peri-implant crestal bone loss [70]. Thus, zirconia modifications need more devotions regarding morphological and bioactive surfaces, which may benefit cell attachment, proliferation, and differentiation during osseointegration.

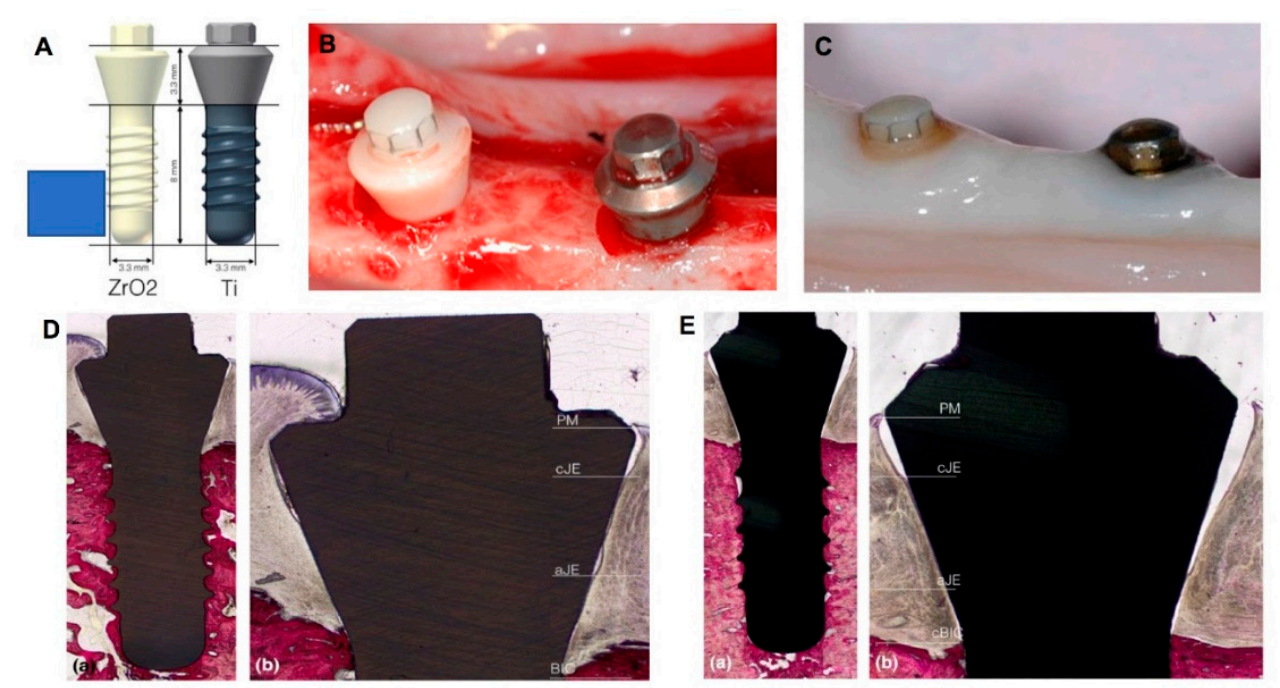

Figure 4. The soft and hard tissues histomorphological outcomes of ceramic and titanium implant. (A) Implant prototypes, (B) implant placement, and (C) soft tissue healing 8 weeks after implant installation. Mesio-distal section of (D) aceramic and (E) titanium implant 8 weeks after implant installation in (a) low or (b) high magnification [71]. Copyright 2016 John Wiley \& Sons A/S.

In order to improve the performance of zirconia surface, multiple physicochemical methods have been utilized, such as machining, grit blasting and acid-etching, ultraviolet light treatment, and laser treatment. These techniques were developed to improve the biological and osseointegration behavior on zirconia implant surface. Gahlert et al. compared the removal torque of machined and grit blasted zirconia implants. The results showed that removal torque values of grit blasting zirconia were nearly twice the values of machined zirconia surfaces $(40.5 \mathrm{~N} / \mathrm{cm}$ vs. $25.9 \mathrm{~N} / \mathrm{cm})$ [72]. In addition, grit blasting can be performed with an additional chemical treatment to improve BIC of zirconia. HF was the most efficient acid to enhance roughness, which is beneficial to osseointegration [73]. However, the maximum acid concentration of HF should be $5 \%$, in order to prevent potential damage of surface hardness and flexural strength on zirconia mechanical structure [74]. The zirconia implants could also form 
superhydrophobic surfaces via UV treatment and make more osteoblast-like cells initially attached to implant surface $[75,76]$. UV application on zirconia has been observed to have decreasing atomic percentage of carbon, and the transformation from hydrophobic to hydrophilic of a zirconia surface was related to the reduction in atomic percentage of surface carbon in a dose-dependent manner from $>50 \%$ down to $<20 \%$ after UV treatment [77]. Laser treatment is a promising alternative to modify zirconia surface and to enhance osseointegration [78]. The zirconia bio-ceramics were considered chemically inert and thus it was hard to promote the process of osseointegration. The $\mathrm{CO}_{2}$ laser can also be used to modify the surface properties, which can induce higher wettability characteristics, enhance the surface energy, and finally obtain osseointegration between bone and bioinert zirconia [79]. Furthermore, micro-grooved surfaces could be constructed by laser treatment on zirconia implants; these microtextures influence peri-implant collagen fiber organization, bone architecture, and cell metabolism [80]. Advances in engineering continuously optimize the bioinert zirconia surfaces, which accelerates osseointegration and shortens the edentulous period of patients in clinical practice.

\section{Coatings on Dental Implants}

The innovations of implant dentistry promote the development of enhancing the biological and mechanical properties of implants. Apart from modified techniques conducting a plastic deformation of the implant surface, by some addictive technologies, we can get depositions of the surface, which are known as coatings. Updating implant coating technologies is the most important approach to achieve better clinical efficacy. Various combinations of multiple surface coatings have been exploited to improve biocompatibility, bioactivity, and antibacterial potentials of implants.

\subsection{Coatings Improving Osseointegration}

Although good osseointegration has been obtained with improvements in surface topography, a great variety of inorganic and organic coatings are continually studied to make dental implants better at tissue integration [81]. Coating bioactive materials onto tough biometals integrates the bone-bonding capacity of bioactive materials and the mechanical performance of the biometals. These bioactive materials comprise hydroxyapatite (HA), magnesium-containing mixed coatings, graphene, several kinds of proteins, et cetera. With different thicknesses and roughness, coatings may influence the chemical inertness, cell adhesion, and antimicrobial properties of the dental implant surface. The following section mainly summarizes recent innovations about bioactive coatings on dental implants.

\subsubsection{HA Layer and Nanocomposites}

Among the different alternatives, coating implants with a layer of HA is one of the most used techniques. HA is a stable and biological form of calcium phosphate, as well as a non-inflammatory, and non-immunogenic material, which strengthens the organic matrix by mineralization [82]. It is composed of ions that normally exist in physiological environments and have excellent osteoconductive and osteointegration properties. Numerous ion-substituted HAs paved a way toward the implant design combined with different bio-functions. Although ion-substituted HA coatings possibly lead to cytotoxic effect that cuts down the proliferation and differentiation of cells attached to the coating surface, these coatings have been proven to have the ability to immensely increase cell attachment [83]. In addition, the HA layer can enhance the bioactivity and osteoconductivity of the Ti substrate. Using a micro-arc oxidation process of making a porous hydroxyapatite-coated surface of titanium alloy would increase the bone-to-implant contact and interface contact rate, which significantly improves the mechanical properties and promotes bone growth [84].

Nano-hydroxyapatite is applied as a kind of single coating, which could be combined with collagen, bioglass, or titanium dioxide in a composite way to simulate the bio-environment of native bones [85]. As the scale of particles decreases to nano-size, their specific surface area and adsorption ability strongly increase. Regardless of time, nano-hydroxyapatite coating provides more bone 
bonding with dental implants compared with normal dual acid-etched surface [86]. The capability of HA coatings to immobilize proteins and growth factors via non-covalent interactions opens new dimensions for preparing hybrid coatings that accelerate bone healing processes. It is reported that biomimetic hydroxyapatite microspheres synthesized from nanocrystalline hydroxyapatites embedded with stromal cell-derived factor-1 (SDF-1) perform excellent biocompatibility and great capacity on bone regeneration in vivo [87]. Ti-6Al-4V implants coated by the nanostructured HA could promote diabetic osteointegration by strengthening osteogenesis and angiogenesis, and further potentially target pathological bone loss [88].

\subsubsection{Magnesium}

Magnesium $(\mathrm{Mg})$ alloys are being studied as biodegradable metal materials due to their mechanical property profile, which resembles the human bone. Magnesium phosphates (MgPs), in general, have higher resorption kinetics and dissolution rates than calcium phosphates (CaPs) in vivo [89]. This makes MgPs more adequate for bioactive and biodegradable materials. Meanwhile, the presence of $\mathrm{Mg}^{2+}$ has been shown to facilitate the proliferation and differentiation of osteoblasts when compared to CaP coatings in vitro [90], and augment new bone formation in vivo [91]. However, one of the biggest shortcomings of magnesium is that corrosion of $\mathrm{Mg}$ alloys on the implant surface occurs quickly in the human physiological environment before the bone fracture is entirely healed. Recently, the microwave irradiation technique is employed to successfully develop various crystal habits of MgPs, which find favorable applications in implant coatings [92]. The mechanism regarding microwave-MgP interactions is still to be investigated. Lee et al. developed a titanium alloy coated with epigallocatechin gallate and $\mathrm{MgCI}_{2}$ consisting of a metal-polyphenol network (MPN) coating, which could improve delivery of osteoinductive $\mathrm{Mg}^{2+}$ with the synergistically improved osseointegration at the bone-implant interface (Figure 5) [93].

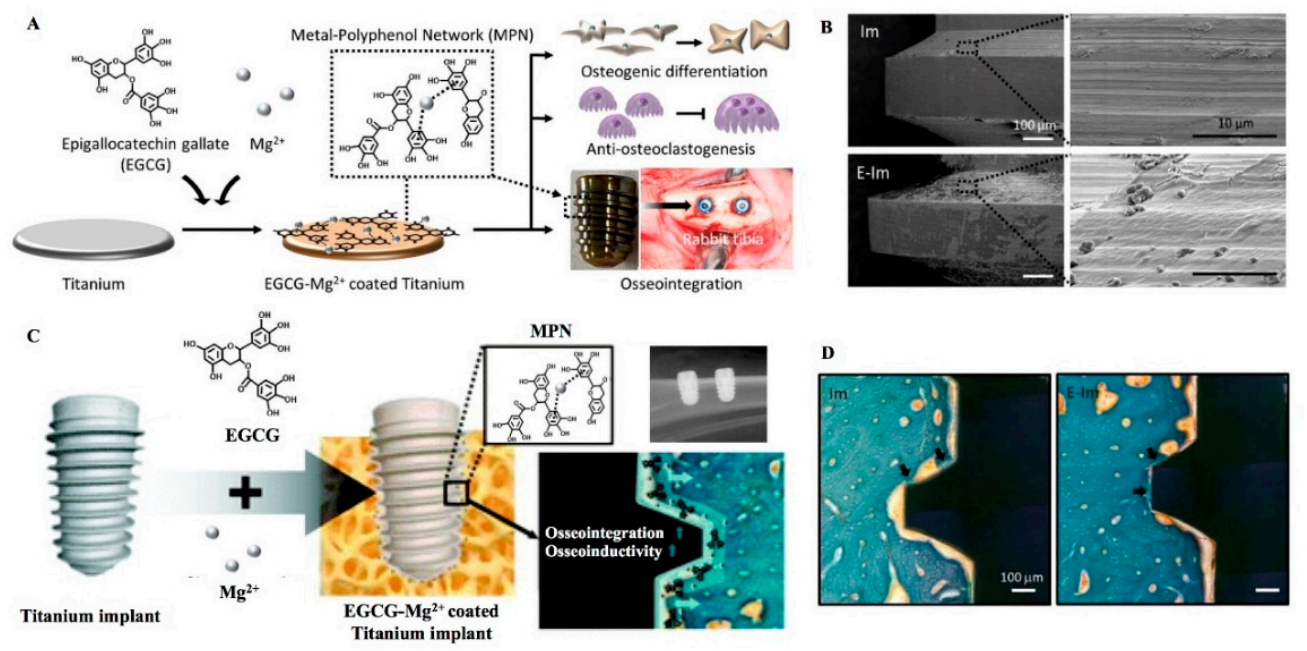

Figure 5. Surface coating of titanium alloy using $\mathrm{Mg}^{2+}$-polyphenol network for improved osseointegration. (A) Schematic diagram of EGCG-Mg ${ }^{2+}$ coating on titanium alloy surface through the formation of a metal-polyphenol network, along with its orthopedic applications; (B) SEM images of the implant (Im) and EGCC-Mg ${ }^{2+}$ coating implant (E-Im); (C) Schematic diagram of E-Im can improve osseointegration; (D) Histological sections of the total threads 4 weeks after implantation on rabbit tibia, black arrow indicates BIC area [93]. Copyright 2020. Reproduced by permission of The Royal Society of Chemistry.

\subsubsection{Graphene}

Graphene is made of carbon consisting of a single layer of atoms, thus it has a high surface area. Also, it can be coated onto metal materials with complex shapes. Because of the two-dimensional 
honeycomb lattice structure, the very small pore size ensure the promising impermeability of graphene. Thus, graphene coating presents excellent structural stability and resistance to mechanochemical degradation; these could effectively prevent corrosion of Ti-6Al-4V implants [94]. Graphene oxide (GO), a novel kind of two-dimensional carbon nano-material, is easy to be functionalized because of a large number of oxygen-containing active surface groups, like carboxyl and hydroxyl groups [95]. Li et al. used the ultrasonic atomization spraying technique to add GO onto the SLA titanium surface. The implant coated with GO effectively enhances the proliferation, adhesion and osteogenic differentiation of BMSCs by inducing the FAK/P38 signaling pathways [96].

\subsubsection{Growth Factor Coatings}

Growth factors applied in implant coatings mainly include vascular endothelial growth factor (VEGF) and bone morphogenetic proteins (BMPs).

VEGF is a signal protein involved in both vasculogenesis and angiogenesis. It is demonstrated that VEGF can enhance the primary rat osteoblast (ROB) proliferation, activate the gene and protein expression of vasculogenesis, and increase the alkaline phosphatase (ALP) activity in vitro. In the corresponding in vivo experiment, coating the implant with VEGF significantly increases the activation of osteoblasts and endothelial cells [97]. In a sheep model, a synergistic effect on better ossification, larger bone trabeculae, and higher angiogenesis degree was found in the silicon substituted hydroxyapatite (SiHA)-coated scaffolds combined with VEGF, compared with SiHA or VEGF coated groups, respectively [98].

BMPs are a family of growth factors, which are of great importance in inducing the formation of bone and cartilage. BMPs can regulate the osteogenic cells and promote the bone mesenchymal stem cells (MSCs) to differentiate [99]. Recombinant techniques are adopted to obtain an adequate yield of BMPs [100]. At present, the Food and Drug Administration (FDA) has approved the recombinant human BMPs (rhBMPs) for therapeutic uses, including rhBMP2 and rhBMP7. Given its addition conduces to BIC, BMPs are increasingly used in implant surface coating applications [101].

BMP-2 incorporated into the octacalcium phosphate (OCP) coating layer is able to enhance the osteoinductivity and improved biocompatibility of coralline hydroxyapatite $(\mathrm{CHA})$ granules, compared with its surface-adsorbed delivery mode [102]. However, more does not necessarily mean better; too high a dose of BMP-2 delivered from the implant surface shows a negative short-term effect on osteogenesis in close vicinity of the implant surface [103]. This is attributed to the induction of osteoclasts by high-dosage BMP-2, which is crucially important in bone remodeling and regulating the osteoblast-osteoclast interactions [104]. According to in vivo rabbit tests, adding both hBMP-2 and hGDF- 5 to implant surface coating can improve the bone formation and osseointegration between host bone and the implant surface [105].

Over the years, BMP-7 shows the potential as a bone regeneration stimulator. It is documented that a locally delivered and very low concentration of BMP-7 can maximize osseointegration by creating a specifical delivery system consisted of poly (ethyl acrylate) coated titanium surface [106]. This system is aimed to effectively control the dose of BMP-7 at the targeted sites.

\subsubsection{Extracellular Matrix Proteins}

Accumulation of extracellular matrix (ECM) proteins onto the implant surfaces is another option to enhance the biocompatibility of dental implants, aiming to regulate cell-matrix adhesion. In the proliferative stage of osseointegration, fibroblast growth factors would stimulate fibroblast to secrete ECM proteins, including elastin, collagen chondroitin sulfate, fibronectin, hyaluronan, and other proteoglycans [107]. Previous literature demonstrated that the coating of collagen-chondroitin sulfate (CS) matrix would increase new bone formation, bone-to-implant contact, as well as bone volume density [108]. Derong Yin et al. found that mussel adhesive protein (MAP) which is biocompatible, biodegradable, and non-toxic, can be a potential titanium implant surface coating. Its physicochemical properties accelerate early cell adhesion and proliferation and promote osteogenic 
cell differentiation [109]. In a rat tibia and femur in vivo study, an engineered, elastin-like protein (ELP) is stably coated on the titanium-base implants (Figure 6). These ELP coatings rapidly promote osseointegration, enable titanium implants to load force at an early stage, and to some extent prevent the micromotion possibly related to aseptic loosening [110].

$\mathbf{A}$

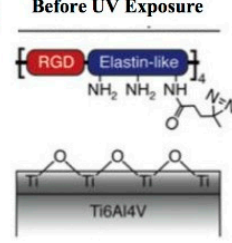

C

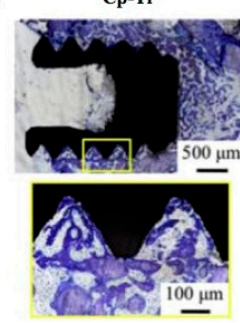

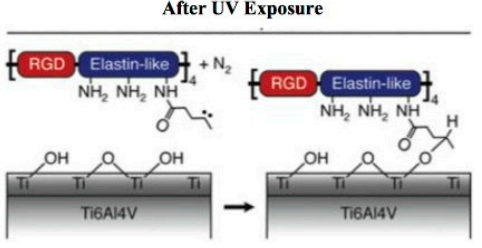

Scrambled ELP

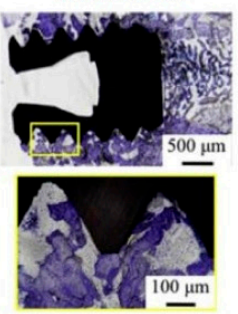

RGD ELP

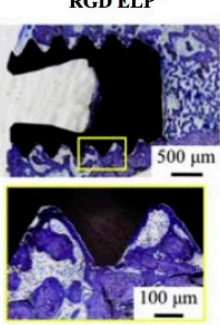

B

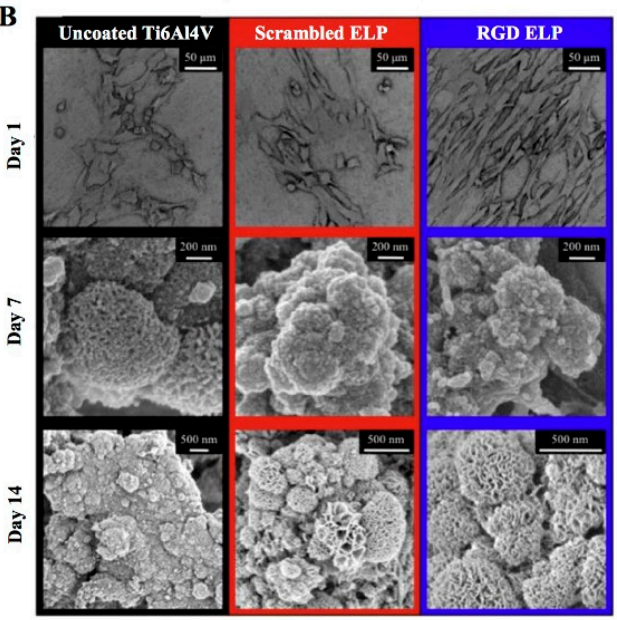

Figure 6. Engineered elastin-like protein (ELP) improve the osseointegration of implants. (A) Schematic of proposed ELP conjugation to titanium substrates upon exposure to UV light; (B) MG63 and mineralization morphology on uncoated, scrambled ELP, and RGD ELP spin coated Ti-6Al-4V. SEM images were taken at 1, 7, and 14 days post-seeding of MG63s in mineralization medium;

(C) Histological sections of inserted screws at 1 week [110]. Copyright 2016 Elsevier Ltd.

\subsection{The Antibacterial Performances of Coating}

Implant-associated infections have become a common postoperative complication of implant restoration, leading to patient dissatisfaction, extra expense, and even implant failure. Bacteria mostly exist in the biofilm attached to the implant surface, which protects the microorganisms inside from antibodies [111]. The excessive application of antibiotics can also promote the proliferation of drug-resistant bacteria. Thus, many scholars tried to find and fabricate modified implants with functional coatings that can prevent bacterial adhesion and biofilm formation, or kill bacteria directly (Figure 7) [112]. In this section, the implant coatings with antibacterial properties were described in detail.

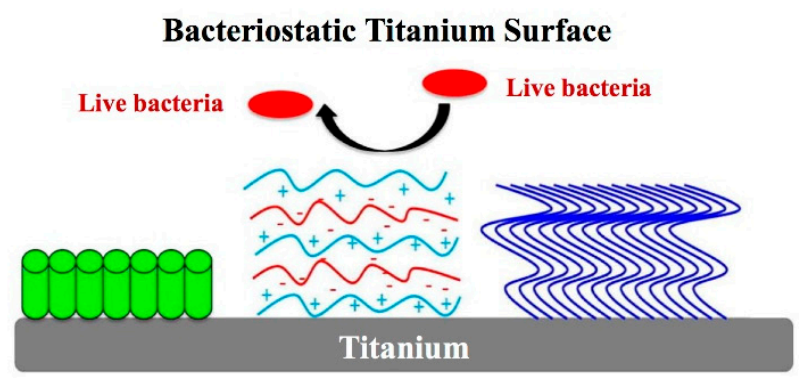

Low surface energy Electrostatic repulsion Exclusion steric repulsion

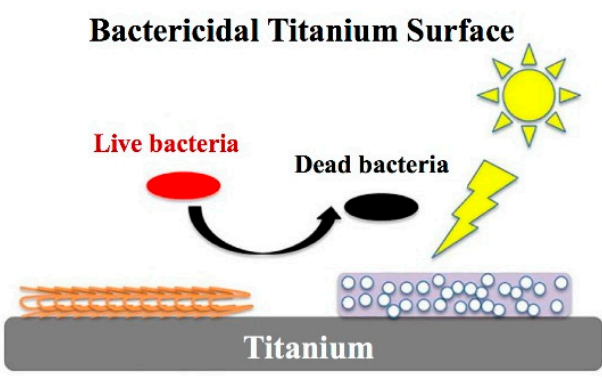

Contact active biocidal

Biocide releasing

Figure 7. Various examples of antimicrobial surfaces according to the mechanism of action: bacteriostatic or bactericidal surfaces. The prevention of biofilm formation by antimicrobial coatings is the best way to prevent primary adhesion or killing approaching bacteria [112]. Copyright 2019 Acta Materialia Inc. 


\subsubsection{Antibiotic Components of Implant Coating}

Doxycycline (DOX) is a widely used antibiotic that inhibits bacteria growth, inflammation, and bone resorption. DOX-treated hydroxyapatite (HA) implant surface was confirmed to attenuate the progression of peri-implantitis in vivo [113]. The release of doxycycline could be controlled by $\mathrm{pH}$ environment for dental implants with the titanium nanotube surface coated with polylactic-co-glycolic acid (PLGA) and DOX [114]. PLGA-amoxicillin-loaded layer on titanium alloy have been proven to have the ability to inhibit bacterial growth of Staphylococcus aureus (S. aureus) and Staphylococcus epidermidis (S. epidermidis) in the first few hours after coating degradation in artificial saliva [115]. Polydopamine (PDA), possessing non-toxic, biocompatible, and adhesive properties, has been applied in coating biomaterials. He et al. reported that cefotaxime sodium immobilized onto polydopamine-coated Ti could help inhibit the Escherichia coli (E. coli, gram-negative) and Streptococcus mutans (S. mutans, gram-positive) from proliferating and adhering to the implant surface. Furthermore, the grafted cefotaxime sodium could keep its long-term antibacterial ability [116]. In addition, new bioactive tetracycline-containing fibers were reported, inhibiting biofilm from forming and progressing into peri-implantitis. This process mostly related to pathogens including Porphyromonas gingivalis (P. gingivalis), Fusobacterium nucleatum (F. nucleatum), Prevotella intermedia (P. intermedia), and Aggregatibacter actinomycetemcomitans (A. actinomycetemcomitans). A marked reduction in bacteria formation was observed with an increase in tetracycline concentration $[117,118]$.

Titanium dioxide nanotubes $\left(\mathrm{TiO}_{2}-\mathrm{NTs}\right)$ on medical-grade titanium surface with good biocompatibility, which can be translated to clinical use by changing the thickness, surface texture, and/or decoration of the nanotubes [119]. $\mathrm{TiO}_{2}-\mathrm{NTs}$ alone are not antimicrobial, but they can obtain antimicrobial properties after coating with antibiotics. To obtain an antibacterial surface with the ability of anti-gram-positive bacteria, vancomycin has been widely used to biofunctionalized Ti [120]. $\mathrm{TiO}_{2}$-NTs loaded with vancomycin showed good antibacterial effect both in vitro and in vivo against S. aureus [121]. Similarly, gentamicin-loaded titanium nanotubes could reduce implant-associated infections in vivo to a great extent [122]. Meanwhile, a novel antibiotic nano-delivery system, silica-gentamycin nanoparticles, showed a continuous ability to release gentamycin and inhibiting S. aureus growth [123]. Furthermore, the dual drug (antibiotics and osteoinductive protein) eluting Ti substrates such as Gentamicin sulfate/BMP-2/heparinized-Ti were a promising material for the enhanced osteointegration and implant longevity in dentistry [124].

\subsubsection{The Antimicrobial Properties of Metal Element Components}

The coatings with antibiotics of dental implants have their limitations, such as narrow antimicrobial spectrum and antibiotic resistance. Alternatively, metal elements such as silver, zinc, and copper have been applied in implant coatings due to their antimicrobial effects and nanoparticulate forms. Silver is well known for its multilevel antimicrobial function, which ensures a wide spectrum and long-term antibacterial character [125]. Silver nanoparticles (AgNPs) can obtain improved physical, chemical, and biological properties. AgNPs are able to penetrate into bacterial cell walls, change the structure of cell membranes and even result in cell death, with the antibacterial mechanisms of contact killing and ion-mediated killing [126]. $\mathrm{TiO}_{2}-\mathrm{NTs}$ decorated with AgNPs exhibited antibacterial properties against S. aureus and showed better biocompatibility with human cells after obtaining a nanoform of HA top coating [127]. Recent studies confirmed that the coating of PDA and AgNPs on the surface of titanium could effectively inhibit the microbial growth against $S$. mutans and P. gingivalis [128,129]. In order to extend the durability of the antibacterial function, researchers employed the AgNPs to decorate both the internal and external space of the synthesized sandwich-structured polydopamine shell, which could be used in vivo to inhibit bacterial infection caused by methicillin-resistant $S$. aureus superbugs and to reduce the biofilm formation [130]. Besides, a surface coating of PDA and AgNPs-loaded $\mathrm{TiO}_{2}$ nanorods $\left(\mathrm{Ag}-\mathrm{TiO}_{2} @ \mathrm{PDA}\right.$ NRDs) was deposited on Ti alloy, exhibiting controlled release of Ag ions with a long-lasting antibacterial ability against E. coli and methicillin-resistant S. aureus [131]. 
It has been widely acknowledged that zinc has the ability to facilitate the process of osseointegration and inhibit bacterial adhesion, both gram-positive and gram-negative bacteria [132,133]. In order to achieve the ability of bacterial inhibition, researchers employ plasma electrolytic oxidation to incorporate zinc into $\mathrm{TiO}_{2}$ coatings of titanium surface, which can greatly inhibit the growth of S. aureus and E. coli. [134]. Also, ZnO@ZnS nanorod-array coating was reported to release optimized zinc, maintaining the high antibacterial efficacy against S. aureus and E. coli [135]. The calcium phosphate coatings incorporated with fluoride and zinc ions were experimentally proven to have bactericidal properties, especially effective in inhibiting the growth, colonization, and adherence of P. gingivalis [136]. Agar diffusion and proliferation tests on S. aureus plasma demonstrated that chemical oxidized titanium $\left(\mathrm{TiOB}^{\circledR}\right)$ coating with ionic zinc showed bactericidal effects compared to those with gentamicin-tannic acid (TiOB ${ }^{\circledR}$ gta) [137]. Besides, zinc oxide ( $\left.\mathrm{ZnO}\right)$ nanoparticles also possess antibacterial properties [138]. Both in vitro and in vivo research conducted by L Grenho et al. verified that the nanoscale hydroxyapatite (nanoHA) finished with different doses of $\mathrm{ZnO}$ nanoparticles could effectively inhibit the bacteria [139]. Furthermore, anaerobic bacteria that colonize around the implants is the major cause for peri-implantitis, and related experiments showed that Glucose-1-phosphate (Glc-1P) biofunctionalized zinc peroxide $\left(\mathrm{ZnO}_{2}\right)$ nanoparticles could inhibit gram-negative anaerobes with a pH-dependent characteristic [140].

Copper nanoparticles (CuNPs) can release copper ions that may be expected to play a dual role in preventing infection and helping with bone formation. CuNPs-derived $\mathrm{TiO}_{2}$ surfaces by an electrochemical process revealed a high biocide potential, which leads to the entire death of S. aureus and E. coli. [141,142]. As shown in Figure 8, a novel Cu-bearing titanium alloy was confirmed to have antimicrobial/antibiofilm activities against S. mutans and P. gingivalis [143]. Copper-functionalized titanium is potent in reducing bacteria attached to the implant surface and surrounding the titanium, which helps to form a "safe zone" for a more stable implant healing environment [144]. In addition, Lee et al. revealed that the antibacterial properties of Ti-Cux alloys may tune the antibacterial properties by changing the $\mathrm{Cu}$ concentration [145].

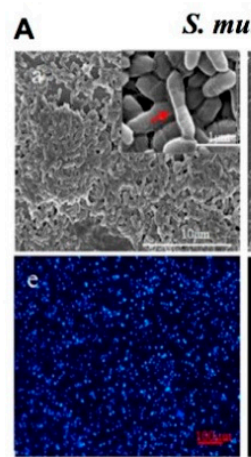

$\mathrm{Ti}$

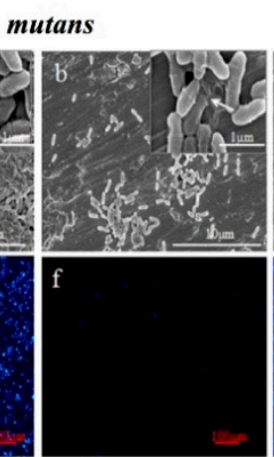

Ti-Cu

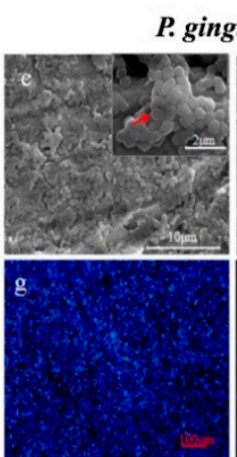

$\mathrm{Ti}$

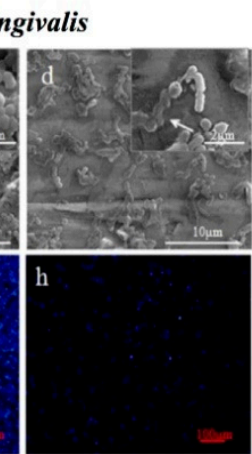

Ti-Cu
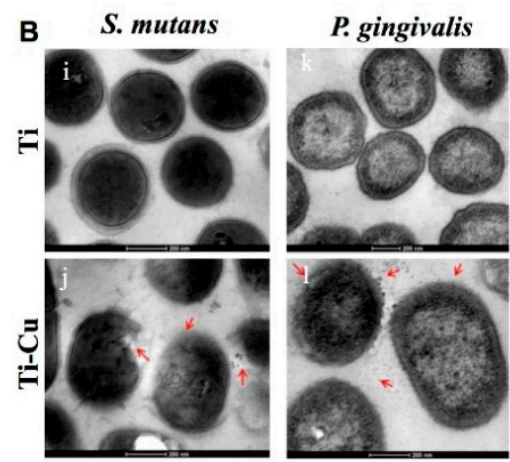

Figure 8. Antibacterial effect of titanium alloy (Ti-Cu). (A) SEM micrographs and DAPI images of S. mutans and P. gingivalis on surfaces of $\mathrm{Ti}(\mathbf{a}, \mathbf{c}, \mathbf{e}, \mathbf{g})$ and Ti-Cu alloy $(\mathbf{b}, \mathbf{d}, \mathbf{f}, \mathbf{h})$ after co-culture for $24 \mathrm{~h}$. (B) TEM micrographs of inner structures of $S$. mutans and P. gingivalis, $(\mathbf{i}, \mathbf{k})$ treated with $\mathrm{Ti} ;(\mathbf{j}, \mathbf{l})$ treated with Ti-Cu alloy [143]. Copyright 2016 Springer Nature.

Ceria oxide $\left(\mathrm{CeO}_{2}\right)$ has superoxide dismutase (SOD) and catalase (CAT) enzymatic activities, which empower it with the capability of reactive oxygen species (ROS)-scavenging. Hence, $\mathrm{CeO}_{2}$ shows promising antibacterial and anti-inflammatory functions. Li et al. employed plasma-spraying to treated the $\mathrm{Ti}$ alloy with $\mathrm{CeO}_{2}$ ceramic powder and found that the $\mathrm{CeO}_{2}$ coating preserved the intracellular antioxidant defense system of $\mathrm{H}_{2} \mathrm{O}_{2}$-treated osteoblasts [146]. The $\mathrm{CeO}_{2}$-incorporated calcium silicate coatings showed strong antimicrobial activity on Enterococcus faecalis, with good biocompatibility [147]. Moreover, nanostructured ceria $\left(\right.$ nano- $-\mathrm{CeO}_{2}$ ) has been demonstrated with the capability of reducing 
bacterial growth and relieving the inflammatory response [148]. Furthermore, different shapes of ceria enclosed by specific crystal planes appeared to enhance the intrinsic catalyzation [149]. As shown in Figure 9, comparing the antibacterial abilities of three different-shaped nano- $\mathrm{CeO}_{2}$ (nanorod, nanocube, and nano-octahedron), nano-octahedron $\mathrm{CeO}_{2}$-modified $\mathrm{Ti}$ was proven to have the best anti-inflammatory effect, while all three types exerted equally strong antibacterial properties [150].

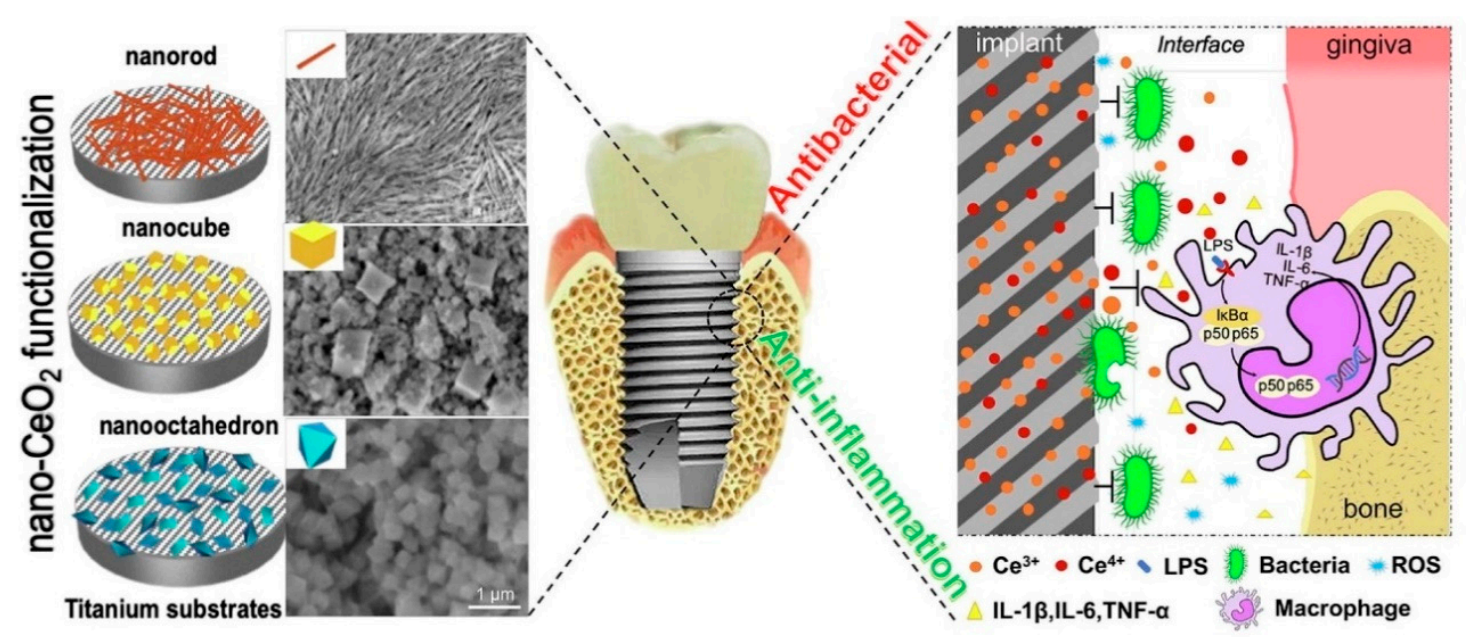

Figure 9. Schematic illustration of implant surface modified by $\mathrm{CeO}_{2}$ nanoparticles for antibacterial and anti-inflammatory properties. The antibacterial effects depend on positively charged $\mathrm{CeO}_{2}$ nanoparticles could probably affect negatively charged bacterial cell surface by electrostatic attraction. In addition, $\mathrm{CeO}_{2}$ nanoparticles inactivate surface protein and decrease the permeability of bacterial cell membranes. For anti-inflammatory properties, $\mathrm{CeO}_{2}$ nanoparticles have both catalase (CAT) and SOD (superoxide dismutase) activities [150]. Copyright 2019 Acta Materialia Inc.

In addition, tantalum-based implants have shown excellent biocompatibility and safety in previous dentistry literature [151]. Related research showed that Tantalum (Ta)-treated Ti surface also demonstrated excellent antimicrobial activity against $F$. nucleatum and $P$. gingivalis, which could also activate the secretion of bone-forming proteins to promote the osseointegration between bone-to-implant surface [152].

Sometimes, different metal elements were also combined in the coatings. For example, Poly (lactic-co-glycolic acid)/Ag/ $\mathrm{ZnO}$ nanorods coating were treated on the titanium surface using a hydrothermal method, and then obtained a long-lasting antibacterial function with good cytocompatibility [153]. Ashley et al. explored a ternary dopant system utilizing $0.25 \mathrm{wt} . \% \mathrm{ZnO}$ to induce osteogenesis, $0.5 \mathrm{wt} . \% \mathrm{SiO}_{2}$ to induce angiogenesis, and $2.0 \mathrm{wt} . \% \mathrm{Ag}_{2} \mathrm{O}$ to provide secondary infection control within a plasma-assisted hydroxyapatite coating for orthopaedic or dental applications [154]. Moreover, the plasma immersion ion implantation system (PIII) could incorporate copper and zinc ions into a titanium nitride (TiN) coated Ti-6Al-4V alloy, which increases both cytocompatibility and the antibacterial ability against $E$. coli [155].

\subsubsection{The Antimicrobial Peptides (AMPs) of Coating Components}

Natural host defense AMPs, a kind of small cationic peptides, have the broad-spectrum antimicrobial activity against a wide range of pathogens, including both gram-positive and gram-negative bacteria, and reduce bacterial resistance responses [156]. AMPs have been used in a wide range of ways, especially the biofunctionalization of Ti with antibacterial properties by covalent immobilization approach [157]. Human lactoferrin 1-11 (hLF1-11) is sensitive to a variety of bacteria without cytotoxicity mammalian cells up to $400 \mu \mathrm{g} / \mathrm{mL}$ [158]. Thus, hLF1-11 has satisfactory antibacterial effects biofunctionalized Ti. Titanium samples, which were treated with hLf1-11, inhibit the Streptococcus sanguinis and Lactobacillus salivarius from adhering to the surface and forming the biofilm at an early stage in vitro $[159,160]$. 
Human beta defensins (HBDs), a family of small AMPs with broad-spectrum antibacterial activities, could protect the oral cavity from being contaminated by various bacteria. Meanwhile, HBDs also have protective immune response and help to facilitate the bone remodeling according to the report [161]. GL13K, a cationic antimicrobial peptide derived from parotid secretory protein, was reported to have bactericidal and bacteriostatic abilities against Pseudomonas aeruginosa, Escherichia coli, and Streptococcus gordonii [162]. GL13K-biofunctionalized titanium is also promising for sustainably reducing the formation of bacterial biofilm, mainly due to its robustness, antimicrobial activity and cytocompatibility. GL13K immobilized onto microgroove surfaces could maintain the peri-implant soft tissues in the long-term [163]. Furthermore, the GL13K coatings are highly stable, which could significantly reduce the number of Streptococcus gordonii and P. gingivalis is cytocompatible with human gingival fibroblasts and osteoblasts in vitro [164,165].

Other AMPs, including Pac-525, KSL, and LL-37, were also reported to inhibit pathogenic bacteria involved in peri-implantitis to some extent, including S. sanguis, F. nucleatum, and P. gingivalis $[166,167]$.

\subsubsection{Polysaccharide Antibacterial Coatings}

Natura Chitosan, a cationic polysaccharide in neutral, is derived from the deacetylation of chitin. The implant surface that was being immobilized with chitosan was proven to have antibacterial properties [168]. Triethoxysilylpropyl succinic anhydride (TESPSA) can form a stable double peptide bond with chitosan as a coupling agent. Campos et al. found a high adhesive resistance of the TESPSA/chitosan coating at the titanium surfaces [169]. Palla-Rubio et al. incorporated silica-chitosan hybrid materials onto titanium implants to improve the antibacterial activity and found that the suitable concentration of $5 \%-10 \%$ for contained chitosan showed antibacterial properties [170]. Also, the antibacterial properties of hyaluronic acid/chitosan polyelectrolyte multilayers against Staphylococcus aureus were approved [171].

Ag-conjugated chitosan nanoparticles coating is promising for the titanium surface, showing an inhibitory effect on the growth of S.mutans and P.gingivalis and suppressing both the bacteria adhesion and the biofilm formation [172,173]. Furthermore, chitosan coatings potentially deliver antimicrobials to reduce the growth of bacteria in a biocompatible way. Chitosan coatings containing $20 \%$ tetracycline or $0.02 \%$ chlorhexidine digluconate were attached to the titanium surface and tested against model pathogens, including Actinobacillus actinomycetemcomitans and Staphylococcus epidermidis. The results showed that coatings released $89 \%$ of tetracycline in 7 days and $100 \%$ chlorhexidine in 2 days, but the released chlorhexidine was toxic to human osteoblasts and fibroblasts [174].

\section{Conclusions and Outlook}

Advances in physical and chemical modification methods have promoted the development of dental implant surfaces to accelerate osseointegration, aiming to shorten the edentulous period of patients. Moreover, attaching biomolecules onto implant surface, such as bioactive compounds and multifunctional molecules, could promote the osteogenetic process around implants, including inducing cell adherence, osteogenic stimulus, or even additional antibacterial effects. Long-term clinical studies are still needed to compare performances of different coatings and assess success rates of novel implant-coating. Moreover, further studies should also examine whether mainstream implant surface treatment and coatings could achieve reliable therapeutic effects, especially in terms of obtaining stability osseointegration, as well as avoiding inflammation, infection, mobility, and mechanical complications. In the future, more optimized coating modified technologies will be exploited for improving the performances of implants, which would be of great benefit for edentulous patients.

Author Contributions: Literature search, writing-original draft preparation, figure rendering, H.D.; writing-review and editing, H.L., L.C., and N.Z.; manuscript correction, Q.L. and G.Y.; Conceptualization, Y.M. All authors have read and agreed to the published version of the manuscript. 
Funding: This review was funded by the National Natural Sciences Foundation of China (81371680), and Jiangsu Provincial Medical Talent (ZDRCC2016016), Key Project of Research and Development Plan of Jiangsu Province (BE2020629), Development of Science and Technology of Nanjing (YKK19094).

Acknowledgments: The authors would like to thank the original authors of Figures and all references for their significant researches contributing to this manuscript.

Conflicts of Interest: The authors declare no conflict of interest.

\section{References}

1. Chrcanovic, B.R.; Kisch, J.; Albrektsson, T.; Wennerberg, A. A retrospective study on clinical and radiological outcomes of oral implants in patients followed up for a minimum of 20 years. Clin. Implant Dent. Relat. Res. 2018, 20, 199-207. [CrossRef] [PubMed]

2. Niedermaier, R.; Stelzle, F.; Riemann, M.; Bolz, W.; Schuh, P.; Wachtel, H. Implant-Supported Immediately Loaded Fixed Full-Arch Dentures: Evaluation of Implant Survival Rates in a Case Cohort of up to 7 Years. Clin. Implant Dent. Relat. Res. 2017, 19, 4-19. [CrossRef]

3. Dong, H.; Zhou, N.; Liu, H.; Huang, H.; Yang, G.; Chen, L.; Ding, M.; Mou, Y. Satisfaction analysis of patients with single implant treatments based on a questionnaire survey. Patient Prefer. Adherence 2019, 13, 695-704. [CrossRef]

4. Zhou, N.; Dong, H.; Zhu, Y.X.; Liu, H.; Zhou, N.; Mou, Y.B. Analysis of implant loss risk factors especially in maxillary molar location: A retrospective study of 6977 implants in Chinese individuals. Clin. Implant Dent. Relat. Res. 2019, 21, 138-144. [CrossRef]

5. Albrektsson, T.; Buser, D.; Sennerby, L. Crestal bone loss and oral implants. Clin. Implant Dent. Relat. Res. 2012, 14, 783-791. [CrossRef]

6. Nguyen-Hieu, T.; Borghetti, A.; Aboudharam, G. Peri-implantitis: From diagnosis to therapeutics. J. Investig. Clin. Dent. 2012, 3, 79-94. [CrossRef]

7. Stanford, C.M.; Keller, J.C. The concept of osseointegration and bone matrix expression. Crit. Rev. Oral Biol. Med. 1991, 2, 83-101. [CrossRef]

8. Albrektsson, T.; Wennerberg, A. On osseointegration in relation to implant surfaces. Clin. Implant Dent. Relat. Res. 2019, 21 (Suppl. 1), 4-7. [CrossRef]

9. Buser, D.; Sennerby, L.; Bruyn, H.D. Modern implant dentistry based on osseointegration: 50 years of progress, current trends and open questions. Periodontology 2000 2017, 73, 7-21. [CrossRef]

10. Buser, D.; Schenk, R.K.; Steinemann, S.; Fiorellini, J.P.; Fox, C.H.; Stich, H. Influence of surface characteristics on bone integration of titanium implants. A histomorphometric study in miniature pigs. J. Biomed. Mater. Res. 1991, 25, 889-902. [CrossRef]

11. Kasemo, B.; Gold, J. Implant surfaces and interface processes. Adv. Dent. Res. 1999, 13, 8-20. [CrossRef] [PubMed]

12. Tuna, T.; Wein, M.; Swain, M.; Fischer, J.; Att, W. Influence of ultraviolet photofunctionalization on the surface characteristics of zirconia-based dental implant materials. Dent. Mater. 2015, 31, e14-e24. [CrossRef] [PubMed]

13. Asensio, G.; Vazquez-Lasa, B.; Rojo, L. Achievements in the Topographic Design of Commercial Titanium Dental Implants: Towards Anti-Peri-Implantitis Surfaces. J. Clin. Med. 2019, 8, 1982. [CrossRef] [PubMed]

14. Subramani, K.; Jung, R.E.; Molenberg, A.; Hammerle, C.H. Biofilm on dental implants: A review of the literature. Int. J. Oral Maxillofac. Implants 2009, 24, 616-626.

15. Liu, L.; Chen, G.; Chao, T.; Ratner, B.D.; Sage, E.H.; Jiang, S. Reduced foreign body reaction to implanted biomaterials by surface treatment with oriented osteopontin. J. Biomater. Sci. Polym. Ed. 2008, 19, 821-835. [CrossRef]

16. Jemat, A.; Ghazali, M.J.; Razali, M.; Otsuka, Y. Surface Modifications and Their Effects on Titanium Dental Implants. Biomed Res. Int. 2015, 2015, 791725. [CrossRef]

17. Linez-Bataillon, P.; Monchau, F.; Bigerelle, M.; Hildebrand, H.F. In vitro MC3T3 osteoblast adhesion with respect to surface roughness of Ti6Al4V substrates. Biomol. Eng. 2002, 19, 133-141. [CrossRef]

18. Bosshardt, D.D.; Chappuis, V.; Buser, D. Osseointegration of titanium, titanium alloy and zirconia dental implants: Current knowledge and open questions. Periodontology 2000 2017, 73, 22-40. [CrossRef] 
19. Cooper, L.F. A role for surface topography in creating and maintaining bone at titanium endosseous implants. J. Prosthet. Dent. 2000, 84, 522-534. [CrossRef]

20. Yurttutan, M.E.; Keskin, A. Evaluation of the effects of different sand particles that used in dental implant roughened for osseointegration. BMC Oral Health 2018, 18, 47. [CrossRef]

21. Piattelli, M.; Scarano, A.; Paolantonio, M.; Iezzi, G.; Petrone, G.; Piattelli, A. Bone response to machined and resorbable blast material titanium implants: An experimental study in rabbits. J. Oral Implantol. 2002, 28, 2-8. [CrossRef]

22. Li, H.F.; Wang, Y.B.; Zheng, Y.F.; Lin, J.P. Osteoblast response on Ti- and Zr-based bulk metallic glass surfaces after sand blasting modification. J. Biomed. Mater. Res. B Appl. Biomater. 2012, 100, 1721-1728. [CrossRef] [PubMed]

23. Gonshor, A.; Goveia, G.; Sotirakis, E. A prospective, multicenter, 4-year study of the ACE Surgical resorbable blast media implant. J. Oral Implantol. 2003, 29, 174-180. [CrossRef]

24. Cha, S.; Park, Y.S. Plasma in dentistry. Clin. Plasma Med. 2014, 2, 4-10. [CrossRef]

25. Cunha, A.; Renz, R.P.; Blando, E.; de Oliveira, R.B.; Hubler, R. Osseointegration of atmospheric plasma-sprayed titanium implants: Influence of the native oxide layer. J. Biomed. Mater. Res. A 2014, 102, 30-36. [CrossRef]

26. Andersen, O.Z.; Offermanns, V.; Sillassen, M.; Almtoft, K.P.; Andersen, I.H.; Sorensen, S.; Jeppesen, C.S.; Kraft, D.C.; Bottiger, J.; Rasse, M.; et al. Accelerated bone ingrowth by local delivery of strontium from surface functionalized titanium implants. Biomaterials 2013, 34, 5883-5890. [CrossRef]

27. Yamaki, K.; Kataoka, Y.; Ohtsuka, F.; Miyazaki, T. Micro-CT evaluation of in vivo osteogenesis at implants processed by wire-type electric discharge machining. Dent. Mater. J. 2012, 31, 427-432. [CrossRef]

28. Lee, Y.J.; Cui, D.Z.; Jeon, H.R.; Chung, H.J.; Park, Y.J.; Kim, O.S.; Kim, Y.J. Surface characteristics of thermally treated titanium surfaces. J. Periodontal Implant Sci. 2012, 42, 81-87. [CrossRef]

29. Shi, X.; Xu, L.; Munar, M.L.; Ishikawa, K. Hydrothermal treatment for TiN as abrasion resistant dental implant coating and its fibroblast response. Mater. Sci. Eng. C Mater. Biol. Appl. 2015, 49, 1-6. [CrossRef]

30. Hindy, A.; Farahmand, F.; Tabatabaei, F.A.-O. In vitro biological outcome of laser application for modification or processing of titanium dental implants. Lasers Med. Sci. 2017, 32, 1197-1206. [CrossRef]

31. Yamazaki, M.; Yamada, M.; Ishizaki, K.; Sakurai, K. Ultraviolet-C irradiation to titanium implants increases peri-implant bone formation without impeding mineralization in a rabbit femur model. Acta Odontol. Scand. 2015, 73, 302-311. [CrossRef]

32. Park, K.H.; Koak, J.Y.; Kim, S.K.; Han, C.H.; Heo, S.J. The effect of ultraviolet-C irradiation via a bactericidal ultraviolet sterilizer on an anodized titanium implant: A study in rabbits. Int. J. Oral Maxillofac. Implants 2013, 28, 57-66. [CrossRef] [PubMed]

33. Mandracci, P.; Mussano, F.; Rivolo, P.; Carossa, S. Surface Treatments and Functional Coatings for Biocompatibility Improvement and Bacterial Adhesion Reduction in Dental Implantology. Coatings 2016, 6, 7. [CrossRef]

34. Roach, M.D.; Williamson, R.S.; Blakely, I.P.; Didier, L.M. Tuning anatase and rutile phase ratios and nanoscale surface features by anodization processing onto titanium substrate surfaces. Mater. Sci. Eng. C Mater. Biol. Appl. 2016, 58, 213-223. [CrossRef]

35. Mangano, F.G.; Pires, J.T.; Shibli, J.A.; Mijiritsky, E.; Iezzi, G.; Piattelli, A.; Mangano, C. Early Bone Response to Dual Acid-Etched and Machined Dental Implants Placed in the Posterior Maxilla: A Histologic and Histomorphometric Human Study. Implant Dent. 2017, 26, 24-29. [CrossRef]

36. Kato, E.; Sakurai, K.; Yamada, M. Periodontal-like gingival connective tissue attachment on titanium surface with nano-ordered spikes and pores created by alkali-heat treatment. Dent. Mater. 2015, 31, e116-e130. [CrossRef]

37. Ribeiro, A.R.; Oliveira, F.; Boldrini, L.C.; Leite, P.E.; Falagan-Lotsch, P.; Linhares, A.B.R.; Zambuzzi, W.F.; Fragneaud, B.; Campos, A.P.C.; Gouvea, C.P.; et al. Micro-arc oxidation as a tool to develop multifunctional calcium-rich surfaces for dental implant applications. Mater. Sci. Eng. C Mater. Biol. Appl. 2015, 54, 196-206. [CrossRef]

38. Chung, C.J.; Su, R.T.; Chu, H.J.; Chen, H.T.; Tsou, H.K.; He, J.L. Plasma electrolytic oxidation of titanium and improvement in osseointegration. J. Biomed. Mater. Res. B Appl. Biomater. 2013, 101, 1023-1030. [CrossRef]

39. Cervino, G.A.-O.; Fiorillo, L.A.-O.; Iannello, G.; Santonocito, D.A.-O.; Risitano, G.A.-O.; Cicciù, M.A.-O. Sandblasted and Acid Etched Titanium Dental Implant Surfaces Systematic Review and Confocal Microscopy Evaluation. Materials 2019, 12, 1763. [CrossRef] 
40. Yeo, I.A.-O. Modifications of Dental Implant Surfaces at the Micro- and Nano-Level for Enhanced Osseointegration. Materials 2019, 13, 89. [CrossRef]

41. Cochran, D.L.; Buser, D.; ten Bruggenkate, C.M.; Weingart, D.; Taylor, T.M.; Bernard, J.P.; Peters, F.; Simpson, J.P. The use of reduced healing times on ITI implants with a sandblasted and acid-etched (SLA) surface: Early results from clinical trials on ITI SLA implants. Clin. Oral Implants Res. 2002, 13, 144-153. [CrossRef]

42. Buser, D.; Broggini, N.; Wieland, M.; Schenk, R.K.; Denzer, A.J.; Cochran, D.L.; Hoffmann, B.; Lussi, A.; Steinemann, S.G. Enhanced bone apposition to a chemically modified SLA titanium surface. J. Dent. Res. 2004, 83, 529-533. [CrossRef]

43. Wennerberg, A.; Galli, S.; Albrektsson, T. Current knowledge about the hydrophilic and nanostructured SLActive surface. Clin. Cosmet. Investig. Dent. 2011, 3, 59-67. [CrossRef]

44. Li, G.; Cao, H.; Zhang, W.; Ding, X.; Yang, G.; Qiao, Y.; Liu, X.; Jiang, X. Enhanced Osseointegration of Hierarchical Micro/Nanotopographic Titanium Fabricated by Microarc Oxidation and Electrochemical Treatment. ACS Appl. Mater. Interfaces 2016, 8, 3840-3852. [CrossRef]

45. Tack, L.; Schickle, K.; Boke, F.; Fischer, H. Immobilization of specific proteins to titanium surface using self-assembled monolayer technique. Dent. Mater. 2015, 31, 1169-1179. [CrossRef]

46. Song, W.; Song, X.; Yang, C.; Gao, S.; Klausen, L.H.; Zhang, Y.; Dong, M.; Kjems, J. Chitosan/siRNA functionalized titanium surface via a layer-by-layer approach for in vitro sustained gene silencing and osteogenic promotion. Int. J. Nanomed. 2015, 10, 2335-2346. [CrossRef]

47. Santander, S.; Alcaine, C.; Lyahyai, J.; Pérez, M.A.; Rodellar, C.; Doblaré, M.; Ochoa, I. In vitro osteoinduction of human mesenchymal stem cells in biomimetic surface modified titanium alloy implants. Dent. Mater. J. 2014, 33, 305-312. [CrossRef]

48. Chen, T.; Wang, S.; He, F.; Guo, Z.; Hu, P.; Zhao, R.; Huang, Y.; Chen, Q.; Ji, P.; Chu, L.; et al. Promotion of Osseointegration Using Protamine/Alginate/Bone Morphogenic Protein 2 Biofunctionalized Composite Coating on Nanopolymorphic Titanium Surfaces. J. Biomed. Nanotechnol. 2018, 14, 933-945. [CrossRef] [PubMed]

49. Wennerberg, A.; Albrektsson, T. On implant surfaces: A review of current knowledge and opinions. Int. J. Oral Maxillofac. Implants 2010, 25, 63-74.

50. Le Guéhennec, L.; Soueidan, A.; Layrolle, P.; Amouriq, Y. Surface treatments of titanium dental implants for rapid osseointegration. Dent. Mater. 2007, 23, 844-854. [CrossRef]

51. Svanborg, L.M.; Andersson, M.; Wennerberg, A. Surface characterization of commercial oral implants on the nanometer level. J. Biomed. Mater. Res. B Appl. Biomater. 2010, 92, 462-469. [CrossRef]

52. Yang, G.; Chen, L.; Gao, Y.; Liu, H.; Dong, H.; Mou, Y. Risk factors and reoperative survival rate of failed narrow-diameter implants in the maxillary anterior region. Clin. Implant Dent. Relat. Res. 2020, 22, $29-41$. [CrossRef]

53. Davidson, J.A.; Mishra, A.K.; Kovacs, P.; Poggie, R.A. New surface-hardened, low-modulus, corrosion-resistant Ti-13Nb-13Zr alloy for total hip arthroplasty. Biomed. Mater. Eng. 1994, 4, 231-243. [CrossRef]

54. Khan, M.A.; Williams, R.L.; Williams, D.F. The corrosion behaviour of Ti-6Al-4V, Ti-6Al-7Nb and Ti-13Nb-13Zr in protein solutions. Biomaterials 1999, 20, 631-637. [CrossRef]

55. Kaur, M.; Singh, K. Review on titanium and titanium based alloys as biomaterials for orthopaedic applications. Mater. Sci. Eng. C Mater. Biol. Appl. 2019, 102, 844-862. [CrossRef]

56. Chikarakara, E.; Fitzpatrick, P.; Moore, E.; Levingstone, T.; Grehan, L.; Higginbotham, C.; Vazquez, M.; Bagga, K.; Naher, S.; Brabazon, D. In vitro fibroblast and pre-osteoblastic cellular responses on laser surface modified Ti-6Al-4V. Biomed. Mater. 2014, 10, 015007. [CrossRef]

57. Gottlow, J.; Dard, M.; Kjellson, F.; Obrecht, M.; Sennerby, L. Evaluation of a new titanium-zirconium dental implant: A biomechanical and histological comparative study in the mini pig. Clin. Implant Dent. Relat. Res. 2012, 14, 538-545. [CrossRef]

58. Saulacic, N.; Bosshardt, D.D.; Bornstein, M.M.; Berner, S.; Buser, D. Bone Apposition to a Titanium-Zirconium Alloy Implant, as Compared to Two Other Titanium-Containing Implants. Eur. Cells Mater. 2012, 23, 273-288. [CrossRef] 
59. Sharma, A.; McQuillan, A.J.; Sharma, L.A.; Waddell, J.N.; Shibata, Y.; Duncan, W.J. Spark anodization of titanium-zirconium alloy: Surface characterization and bioactivity assessment. J. Mater. Sci. Mater. Med. 2015, 26, 221. [CrossRef]

60. Egusa, H.; Ko, N.; Shimazu, T.; Yatani, H. Suspected association of an allergic reaction with titanium dental implants: A clinical report. J. Prosthet. Dent. 2008, 100, 344-347. [CrossRef]

61. Oliveira, V.M.C.A.; Aguiar, C.; Vazquez, A.M.; Robin, A.; Barboza, M.J.R. Improving corrosion resistance of Ti-6Al-4V alloy through plasma-assisted PVD deposited nitride coatings. Corros. Sci. 2014, 88, 317-327. [CrossRef]

62. Wang, S.; Liu, Y.; Zhang, C.; Liao, Z.; Liu, W. The improvement of wettability, biotribological behavior and corrosion resistance of titanium alloy pretreated by thermal oxidation. Tribol. Int. 2014, 79, 174-182. [CrossRef]

63. Xu, G.; Shen, X.; Hu, Y.; Ma, P.; Cai, K. Fabrication of tantalum oxide layers onto titanium substrates for improved corrosion resistance and cytocompatibility. Surf. Coat. Technol. 2015, 272, 58-65. [CrossRef]

64. Mokgalaka, M.N.; Popoola, A.P.I.; Pityana, S.L. In situ laser deposition of NiTi intermetallics for corrosion improvement of Ti-6Al-4V alloy. Trans. Nonferrous Metals Soc. China 2015, 25, 3315-3322. [CrossRef]

65. Bartolomeu, F.; Buciumeanu, M.; Pinto, E.; Alves, N.; Silva, F.S.; Carvalho, O.; Miranda, G. Wear behavior of Ti6Al4V biomedical alloys processed by selective laser melting, hot pressing and conventional casting. Trans. Nonferrous Metals Soc. China 2017, 27, 829-838. [CrossRef]

66. Zhang, J.; Gan, X.; Tang, H.; Zhan, Y. Enhancement of wear and corrosion resistance of low modulus $\beta$-type Zr-20Nb-xTi $(x=0,3)$ dental alloys through thermal oxidation treatment. Mater. Sci. Eng. C Mater. Biol. Appl. 2017, 76, 260-268. [CrossRef] [PubMed]

67. Hashim, D.; Cionca, N.; Courvoisier, D.S.; Mombelli, A. A systematic review of the clinical survival of zirconia implants. Clin. Oral Investig. 2016, 20, 1403-1417. [CrossRef]

68. Stadlinger, B.; Hennig, M.; Eckelt, U.; Kuhlisch, E.; Mai, R. Comparison of zirconia and titanium implants after a short healing period. A pilot study in minipigs. Int. J. Oral Maxillofac. Surg. 2010, 39, 585-592. [CrossRef] [PubMed]

69. Scarano, A.; Di Carlo, F.; Quaranta, M.; Piattelli, A. Bone response to zirconia ceramic implants: An experimental study in rabbits. J. Oral Implantol. 2003, 29, 8-12. [CrossRef]

70. Kohal, R.J.; Schwindling, F.S.; Bachle, M.; Spies, B.C. Peri-implant bone response to retrieved human zirconia oral implants after a 4-year loading period: A histologic and histomorphometric evaluation of 22 cases. J. Biomed. Mater. Res. B Appl. Biomater. 2016, 104, 1622-1631. [CrossRef]

71. Liñares, A.; Grize, L.; Muñoz, F.A.-O.; Pippenger, B.E.; Dard, M.; Domken, O.; Blanco-Carrión, J. Histological assessment of hard and soft tissues surrounding a novel ceramic implant: A pilot study in the minipig. J. Clin. Periodontol. 2016, 43, 538-546. [CrossRef] [PubMed]

72. Gahlert, M.; Gudehus, T.; Eichhorn, S.; Steinhauser, E.; Kniha, H.; Erhardt, W. Biomechanical and histomorphometric comparison between zirconia implants with varying surface textures and a titanium implant in the maxilla of miniature pigs. Clin. Oral Implant. Res. 2007, 18, 662-668. [CrossRef] [PubMed]

73. Gahlert, M.; Rohling, S.; Wieland, M.; Eichhorn, S.; Kuchenhoff, H.; Kniha, H. A comparison study of the osseointegration of zirconia and titanium dental implants. A biomechanical evaluation in the maxilla of pigs. Clin. Implant Dent. Relat. Res. 2010, 12, 297-305. [CrossRef] [PubMed]

74. Xie, H.; Shen, S.; Qian, M.; Zhang, F.; Chen, C.; Tay, F.R. Effects of Acid Treatment on Dental Zirconia: An in Vitro Study. PLoS ONE 2015, 10, e0136263. [CrossRef]

75. Watanabe, H.; Saito, K.; Kokubun, K.; Sasaki, H.; Yoshinari, M. Change in surface properties of zirconia and initial attachment of osteoblastlike cells with hydrophilic treatment. Dent. Mater. J. 2012, 31, 806-814. [CrossRef]

76. Henningsen, A.; Smeets, R.; Heuberger, R.; Jung, O.T.; Hanken, H.; Heiland, M.; Cacaci, C.; Precht, C. Changes in surface characteristics of titanium and zirconia after surface treatment with ultraviolet light or non-thermal plasma. Eur. J. Oral Sci. 2018, 126, 126-134. [CrossRef] [PubMed]

77. Brezavšček, M.; Fawzy, A.; Bächle, M.; Tuna, T.; Fischer, J.; Att, W. The Effect of UV Treatment on the Osteoconductive Capacity of Zirconia-Based Materials. Materials 2016, 9, 958. [CrossRef]

78. Liu, D.; Matinlinna, J.P.; Tsoi, J.K.; Pow, E.H.; Miyazaki, T.; Shibata, Y.; Kan, C.W. A new modified laser pretreatment for porcelain zirconia bonding. Dent. Mater. 2013, 29, 559-565. [CrossRef] 
79. Hao, L.; Lawrence, J.; Chian, K.S. Osteoblast cell adhesion on a laser modified zirconia based bioceramic. J. Mater. Sci. Mater. Med. 2005, 16, 719-726. [CrossRef]

80. Delgado-Ruiz, R.A.; Abboud, M.; Romanos, G.; Aguilar-Salvatierra, A.; Gomez-Moreno, G.; Calvo-Guirado, J.L. Peri-implant bone organization surrounding zirconia-microgrooved surfaces circularly polarized light and confocal laser scanning microscopy study. Clin. Oral Implants Res. 2015, 26, 1328-1337. [CrossRef]

81. Cicciù, M.; Fiorillo, L.; Herford, A.S.; Crimi, S.; Bianchi, A.; D’Amico, C.; Laino, L.; Cervino, G. Bioactive Titanium Surfaces: Interactions of Eukaryotic and Prokaryotic Cells of Nano Devices Applied to Dental Practice. Biomedicines 2019, 7, 12. [CrossRef] [PubMed]

82. López-Valverde, N.; Flores-Fraile, J.; Ramírez, J.; Sousa, B.; Herrero-Hernández, S.; López-Valverde, A. Bioactive Surfaces vs. Conventional Surfaces in Titanium Dental Implants: A Comparative Systematic Review. J. Clin. Med. 2020, 9, 2047. [CrossRef]

83. Qadir, M.; Li, Y.; Wen, C.J.A.B. Ion-substituted calcium phosphate coatings by physical vapor deposition magnetron sputtering for biomedical applications: A review. Acta Biomater. 2019, 89, 14-32. [CrossRef] [PubMed]

84. Jing, W.S.; Zhang, M.H.; Jin, L.; Zhao, J.; Gao, Q.; Ren, M.; Fan, Q.Y. Assessment of osteoinduction using a porous hydroxyapatite coating prepared by micro-arc oxidation on a new titanium alloy. Int. J. Surg. 2015, 24, 51-56. [CrossRef]

85. Choi, A.; Ben-Nissan, B.; Matinlinna, J.; Conway, R.C. Current perspectives: Calcium phosphate nanocoatings and nanocomposite coatings in dentistry. J. Dent. Res. 2013, 92, 853-859. [CrossRef]

86. Bergamo, E.; Pessoa, P.; Jimbo, R.; Neiva, R.; Coelho, P. The synergetic effect of implant macrogeometry and surface physicochemical modifications on osseointegration: An in vivo experimental study in sheep. J. Long-Term Eff. Med. Implant. 2020, 29, 295-302. [CrossRef]

87. Fang, C.-H.; Lin, Y.-W.; Lin, F.-H.; Sun, J.-S.; Chao, Y.-H.; Lin, H.-Y.; Chang, Z.-C. Biomimetic Synthesis of Nanocrystalline Hydroxyapatite Composites: Therapeutic Potential and Effects on Bone Regeneration. Int. J. Mol. Sci. 2019, 20, 6002. [CrossRef]

88. Hu, Z.; Wang, X.; Xia, W.; Wang, Z.; Zhang, P.; Xia, L.; Lin, K.; Zhu, M. Nano-Structure Designing Promotion Osseointegration of Hydroxyapatite Coated Ti-6Al-4V Alloy Implants in Diabetic Model. J. Biomed. Nanotechnol. 2019, 15, 1701-1713. [CrossRef]

89. Ewald, A.; Kreczy, D.; Brückner, T.; Gbureck, U.; Bengel, M.; Hoess, A.; Nies, B.; Bator, J.; Klammert, U.; Fuchs, A.J.M. Development and Bone Regeneration Capacity of Premixed Magnesium Phosphate Cement Pastes. Materials 2019, 12, 2119. [CrossRef]

90. Nabiyouni, M.; Ren, Y.; Bhaduri, S.B. Magnesium substitution in the structure of orthopedic nanoparticles: A comparison between amorphous magnesium phosphates, calcium magnesium phosphates, and hydroxyapatites. Mater. Sci. Eng. C 2015, 52,11-17. [CrossRef]

91. Pardun, K.; Treccani, L.; Volkmann, E.; Streckbein, P.; Heiss, C.; Gerlach, J.W.; Maendl, S.; Rezwan, K. Magnesium-containing mixed coatings on zirconia for dental implants: Mechanical characterization and in vitro behavior. J. Biomater. Appl. 2015, 30, 104-118. [CrossRef]

92. Sikder, P.; Bhaduri, S.B. Microwave assisted synthesis and characterization of single-phase tabular hexagonal newberyite, an important bioceramic. J. Am. Ceram. Soc. 2018, 101, 2537-2544. [CrossRef]

93. Lee, S.; Chang, Y.-Y.; Lee, J.; Perikamana, S.K.M.; Kim, E.M.; Jung, Y.-H.; Yun, J.-H.; Shin, H. Surface engineering of titanium alloy using metal-polyphenol network coating with magnesium ions for improved osseointegration. Biomater. Sci. 2020, 8, 3404-3417. [CrossRef] [PubMed]

94. Malhotra, R.; Han, Y.; Morin, J.; Luong-Van, E.; Chew, R.; Neto, A.C.; Nijhuis, C.; Rosa, V. Inhibiting Corrosion of Biomedical-Grade Ti-6Al-4V Alloys with Graphene Nanocoating. J. Dent. Res. 2020, 99, $285-292$. [CrossRef] [PubMed]

95. Shin, S.R.; HaeLin, J.; Jang, H.L.; Khoshakhlagh, P.; Akbari, M.; Nasajpour, A.; Zhang, Y.S.; Tamayol, A.; Khademhosseini, A. Graphene-based materials for tissue engineering. Adv. Drug Deliv. Rev. 2016, 105, 255-274. [CrossRef] [PubMed]

96. Li, Q.; Wang, Z. Involvement of FAK/P38 Signaling Pathways in Mediating the Enhanced Osteogenesis Induced by Nano-Graphene Oxide Modification on Titanium Implant Surface. Int. J. Nanomed. 2020, 15, 4659-4676. [CrossRef] 
97. Guang, M.; Huang, B.; Yao, Y.; Zhang, L.; Yang, B.; Gong, P. Effects of vascular endothelial growth factor on osteoblasts around dental implants in vitro and in vivo. J. Oral Sci. 2017, 59, 215-223. [CrossRef]

98. Izquierdo-Barba, I.; Santos-Ruiz, L.; Becerra, J.; Feito, M.; Fernández-Villa, D.; Serrano, M.; Díaz-Güemes, I.; Fernández-Tomé, B.; Enciso, S.; Sánchez-Margallo, F.; et al. Synergistic effect of Si-hydroxyapatite coating and VEGF adsorption on Ti6Al4V-ELI scaffolds for bone regeneration in an osteoporotic bone environment. Acta Biomater. 2019, 83, 456-466. [CrossRef]

99. Katagiri, T.; Watabe, T. Bone Morphogenetic Proteins. Cold Spring Harb. Perspect. Biol. 2016, 8, a021899. [CrossRef]

100. Carreira, A.C.; Lojudice, F.H.; Halcsik, E.; Navarro, R.D.; Sogayar, M.C.; Granjeiro, J.M. Bone Morphogenetic Proteins Facts, Challenges, and Future Perspectives. J. Dent. Res. 2014, 93, 335. [CrossRef]

101. Kim, J.-E.; Kang, S.-S.; Choi, K.-H.; Shim, J.-S.; Jeong, C.-M.; Shin, S.-W.; Huh, J.-B. The effect of anodized implants coated with combined rhBMP-2 and recombinant human vascular endothelial growth factors on vertical bone regeneration in the marginal portion of the peri-implant. Oral Surgery Oral Med. Oral Pathol. Oral Radiol. 2013, 115, e24-e31. [CrossRef] [PubMed]

102. Lin, X.; Eb, H.; Liu, T.; Hu, Q.; Liu, Y. Enhanced biocompatibility and improved osteogenesis of coralline hydroxyapatite modified by bone morphogenetic protein 2 incorporated into a biomimetic coating. Mater. Sci. Eng. C 2019, 96, 329-336. [CrossRef] [PubMed]

103. Guillot, R.; Pignot-Paintrand, I.; Lavaud, J.; Decambron, A.; Bourgeois, E.; Josserand, V.; Logeart-Avramoglou, D.; Viguier, E.; Picart, C. Assessment of a polyelectrolyte multilayer film coating loaded with BMP-2 on titanium and PEEK implants in the rabbit femoral condyle. Acta Biomater. 2016, 36, 310-322. [CrossRef] [PubMed]

104. Santo, V.E.; Gomes, M.E.; Mano, J.F.; Reis, R.L. Controlled release strategies for bone, cartilage, and osteochondral engineering - Part I: Recapitulation of native tissue healing and variables for the design of delivery systems. Tissue Eng. Part B Rev. 2013, 19, 308-326. [CrossRef]

105. Yang, D.H.; Moon, S.W.; Lee, D.W. Surface Modification of Titanium with BMP-2/GDF-5 by a Heparin Linker and Its Efficacy as a Dental Implant. Int. J. Mol. Sci. 2017, 18, 229. [CrossRef]

106. Al-Jarsha, M.; Moulisova, V.; Leal-Egana, A.; Connell, A.; Naudi, K.B.; Ayoub, A.F.; Dalby, M.J.; Salmerón-Sánchez, M. Engineered Coatings for Titanium Implants to Present Ultralow Doses of BMP-7. ACS Biomater. Sci. Eng. 2018, 4, 1812-1819. [CrossRef]

107. Terheyden, H.; Lang, N.P.; Bierbaum, S.; Stadlinger, B. Osseointegration-Communication of cells. Clin. Oral Implant. Res. 2012, 23, 1127-1135. [CrossRef]

108. Kellesarian, S.V.; Malignaggi, V.; Kellesarian, T.; Ahmed, H.B.; Javed, F. Does incorporating collagen and chondroitin sulfate matrix in implant surfaces enhance osseointegration? A systematic review and meta-analysis. Int. J. Oral Maxillofac. Surg. 2018, 47, 241-251. [CrossRef] [PubMed]

109. Yin, D.; Komasa, S.; Yoshimine, S.; Sekino, T.; Okazaki, J. Effect of mussel adhesive protein coating on osteogenesis in vitro and osteointegration in vivo to alkali-treated titanium with nanonetwork structures. Int. J. Nanomed. 2019, 14, 3831-3843. [CrossRef]

110. Raphel, J.; Karlsson, J.; Galli, S.; Wennerberg, A.; Lindsay, C.; Haugh, M.G.; Pajarinen, J.; Goodman, S.B.; Jimbo, R.; Andersson, M.; et al. Engineered protein coatings to improve the osseointegration of dental and orthopaedic implants. Biomaterials 2016, 83, 269-282. [CrossRef]

111. Franci, G.; Falanga, A.; Galdiero, S.; Palomba, L.; Rai, M.; Morelli, G.; Galdiero, M. Silver Nanoparticles as Potential Antibacterial Agents. Molecules 2015, 20, 8856-8874. [CrossRef] [PubMed]

112. Chouirfa, H.; Bouloussa, H.; Migonney, V.; Falentin-Daudré, C. Review of titanium surface modification techniques and coatings for antibacterial applications. Acta Biomater. 2019, 83, 37-54. [CrossRef] [PubMed]

113. Ding, L.; Zhang, P.; Wang, X.; Kasugai, S. A doxycycline-treated hydroxyapatite implant surface attenuates the progression of peri-implantitis: A radiographic and histological study in mice. Clin. Implant Dent. Relat. Res. 2019, 21, 154-159. [CrossRef] [PubMed]

114. Alecio, A.B.W.; Ferreira, C.F.; Babu, J.; Shokuhfar, T.; Jo, S.; Magini, R.; Garcia-Godoy, F. Doxycycline Release of Dental Implants with Nanotube Surface, Coated with Poly Lactic-Co-Glycolic Acid for Extended pH-controlled Drug Delivery. J. Oral Implantol. 2019, 45, 267-273. [CrossRef] 
115. Kazek-Kesik, A.; Nosol, A.; Plonka, J.; Smiga-Matuszowicz, M.; Golda-Cepa, M.; Krok-Borkowicz, M.; Brzychczy-Wloch, M.; Pamula, E.; Simka, W. PLGA-amoxicillin-loaded layer formed on anodized Ti alloy as a hybrid material for dental implant applications. Mater. Sci. Eng. C Mater. Biol. Appl. 2019, 94, 998-1008. [CrossRef] [PubMed]

116. He, S.; Zhou, P.; Wang, L.X.; Xiong, X.L.; Zhang, Y.F.; Deng, Y.; Wei, S.C. Antibiotic-decorated titanium with enhanced antibacterial activity through adhesive polydopamine for dental/bone implant. J. R. Soc. Interface 2014, 11, 20140169. [CrossRef] [PubMed]

117. Shahi, R.G.; Albuquerque, M.T.P.; Munchow, E.A.; Blanchard, S.B.; Gregory, R.L.; Bottino, M.C. Novel bioactive tetracycline-containing electrospun polymer fibers as a potential antibacterial dental implant coating. Odontology 2017, 105, 354-363. [CrossRef]

118. Bottino, M.C.; Munchow, E.A.; Albuquerque, M.T.P.; Kamocki, K.; Shahi, R.; Gregory, R.L.; Chu, T.M.G.; Pankajakshan, D. Tetracycline-incorporated polymer nanofibers as a potential dental implant surface modifier. J. Biomed. Mater. Res. Part B-Appl. Biomater. 2017, 105, 2085-2092. [CrossRef]

119. Spriano, S.; Yamaguchi, S.; Baino, F.; Ferraris, S. A critical review of multifunctional titanium surfaces: New frontiers for improving osseointegration and host response, avoiding bacteria contamination. Acta Biomater. 2018, 79, 1-22. [CrossRef]

120. Hickok, N.J.; Shapiro, I.M. Immobilized antibiotics to prevent orthopaedic implant infections. Adv. Drug Deliv. Rev. 2012, 64, 1165-1176. [CrossRef]

121. Zhang, H.; Sun, Y.; Tian, A.; Xue, X.X.; Wang, L.; Alquhali, A.; Bai, X. Improved antibacterial activity and biocompatibility on vancomycin-loaded $\mathrm{TiO}_{2}$ nanotubes: In vivo and in vitro studies. Int. J. Nanomed. 2013, 8, 4379-4389. [CrossRef] [PubMed]

122. Yang, Y.; Ao, H.Y.; Yang, S.B.; Wang, Y.G.; Lin, W.T.; Yu, Z.F.; Tang, T.T. In vivo evaluation of the anti-infection potential of gentamicin-loaded nanotubes on titania implants. Int. J. Nanomed. 2016, 11, 2223-2234. [CrossRef]

123. Wang, J.; Wu, G.; Liu, X.; Sun, G.; Li, D.; Wei, H. A decomposable silica-based antibacterial coating for percutaneous titanium implant. Int. J. Nanomed. 2017, 12, 371-379. [CrossRef] [PubMed]

124. Lee, D.W.; Yun, Y.P.; Park, K.; Kim, S.E. Gentamicin and bone morphogenic protein-2 (BMP-2)-delivering heparinized-titanium implant with enhanced antibacterial activity and osteointegration. Bone 2012, 50, 974-982. [CrossRef] [PubMed]

125. Lampe, I.; Beke, D.; Biri, S.; Csarnovics, I.; Csik, A.; Dombradi, Z.; Hajdu, P.; Hegedus, V.; Racz, R.; Varga, I.; et al. Investigation of silver nanoparticles on titanium surface created by ion implantation technology. Int. J. Nanomed. 2019, 14, 4709-4721. [CrossRef] [PubMed]

126. Yin, I.X.; Zhang, J.; Zhao, I.S.; Mei, M.L.; Li, Q.; Chu, C.H. The Antibacterial Mechanism of Silver Nanoparticles and Its Application in Dentistry. Int. J. Nanomed. 2020, 15, 2555-2562. [CrossRef] [PubMed]

127. Gunputh, U.F.; Le, H.; Lawton, K.; Besinis, A.; Tredwin, C.; Handy, R.D. Antibacterial properties of silver nanoparticles grown in situ and anchored to titanium dioxide nanotubes on titanium implant against Staphylococcus aureus. Nanotoxicology 2020, 14, 97-110. [CrossRef]

128. Choi, S.H.; Jang, Y.S.; Jang, J.H.; Bae, T.S.; Lee, S.J.; Lee, M.H. Enhanced antibacterial activity of titanium by surface modification with polydopamine and silver for dental implant application. J. Appl. Biomater. Funct. Mater. 2019, 17, 2280800019847067. [CrossRef]

129. Li, M.; Liu, Q.; Jia, Z.; Xu, X.; Shi, Y.; Cheng, Y.; Zheng, Y. Polydopamine-induced nanocomposite Ag/CaP coatings on the surface of titania nanotubes for antibacterial and osteointegration functions. J. Mater. Chem. B 2015, 3, 8796-8805. [CrossRef]

130. Shang, B.; Xu, M.; Zhi, Z.; Xi, Y.; Wang, Y.; Peng, B.; Li, P.; Deng, Z. Synthesis of sandwich-structured silver@polydopamine@silver shells with enhanced antibacterial activities. J. Colloid Interface Sci. 2020, 558, 47-54. [CrossRef]

131. Guan, M.; Chen, Y.; Wei, Y.; Song, H.; Gao, C.; Cheng, H.; Li, Y.; Huo, K.; Fu, J.; Xiong, W. Long-lasting bactericidal activity through selective physical puncture and controlled ions release of polydopamine and silver nanoparticles-loaded $\mathrm{TiO}(2)$ nanorods in vitro and in vivo. Int. J. Nanomed. 2019, 14, 2903-2914. [CrossRef] [PubMed]

132. Chou, A.H.; LeGeros, R.Z.; Chen, Z.; Li, Y. Antibacterial effect of zinc phosphate mineralized guided bone regeneration membranes. Implant Dent. 2007, 16, 89-100. [CrossRef] [PubMed] 
133. Shen, X.; Hu, Y.; Xu, G.; Chen, W.; Xu, K.; Ran, Q.; Ma, P.; Zhang, Y.; Li, J.; Cai, K. Regulation of the biological functions of osteoblasts and bone formation by $\mathrm{Zn}$-incorporated coating on microrough titanium. ACS Appl. Mater. Interfaces 2014, 6, 16426-16440. [CrossRef] [PubMed]

134. Hu, H.; Zhang, W.; Qiao, Y.; Jiang, X.; Liu, X.; Ding, C. Antibacterial activity and increased bone marrow stem cell functions of $\mathrm{Zn}$-incorporated $\mathrm{TiO}_{2}$ coatings on titanium. Acta Biomater. 2012, 8, 904-915. [CrossRef]

135. Luo, Q.; Cao, H.; Wang, L.; Ma, X.; Liu, X. ZnO@ZnS nanorod-array coated titanium: Good to fibroblasts but bad to bacteria. J. Colloid Interface Sci. 2020, 579, 50-60. [CrossRef] [PubMed]

136. Kulkarni Aranya, A.; Pushalkar, S.; Zhao, M.; LeGeros, R.Z.; Zhang, Y.; Saxena, D. Antibacterial and bioactive coatings on titanium implant surfaces. J. Biomed. Mater. Res. A 2017, 105, 2218-2227. [CrossRef]

137. Kranz, S.; Guellmar, A.; Voelpel, A.; Lesser, T.; Tonndorf-Martini, S.; Schmidt, J.; Schrader, C.; Faucon, M.; Finger, U.; Pfister, W.; et al. Bactericidal and Biocompatible Properties of Plasma Chemical Oxidized Titanium $\left(\mathrm{TiOB}\left({ }^{\circledR}\right)\right)$ with Antimicrobial Surface Functionalization. Materials 2019, 12, 866. [CrossRef]

138. Mahamuni-Badiger, P.P.; Patil, P.M.; Badiger, M.V.; Patel, P.R.; Thorat-Gadgil, B.S.; Pandit, A.; Bohara, R.A. Biofilm formation to inhibition: Role of zinc oxide-based nanoparticles. Mater. Sci. Eng. C Mater. Biol. Appl. 2020, 108, 110319. [CrossRef]

139. Grenho, L.; Salgado, C.L.; Fernandes, M.H.; Monteiro, F.J.; Ferraz, M.P. Antibacterial activity and biocompatibility of three-dimensional nanostructured porous granules of hydroxyapatite and zinc oxide nanoparticles-An in vitro and in vivo study. Nanotechnology 2015, 26, 315101. [CrossRef]

140. Fröber, K.; Bergs, C.; Pich, A.; Conrads, G. Biofunctionalized zinc peroxide nanoparticles inhibit peri-implantitis associated anaerobes and Aggregatibacter actinomycetemcomitans $\mathrm{pH}$-dependent. Anaerobe 2020, 62, 102153. [CrossRef]

141. Rosenbaum, J.; Versace, D.L.; Abbad-Andallousi, S.; Pires, R.; Azevedo, C.; Cénédese, P.; Dubot, P.A.-O. Antibacterial properties of nanostructured $\mathrm{Cu}-\mathrm{TiO}(2)$ surfaces for dental implants. Biomater. Sci. 2017, 5, 455-462. [CrossRef]

142. Wang, X.; Dong, H.; Liu, J.; Qin, G.; Chen, D.; Zhang, E. In vivo antibacterial property of Ti-Cu sintered alloy implant. Mater. Sci. Eng. C Mater. Biol. Appl. 2019, 100, 38-47. [CrossRef]

143. Liu, R.; Memarzadeh, K.; Chang, B.; Zhang, Y.; Ma, Z.; Allaker, R.P.; Ren, L.; Yang, K. Antibacterial effect of copper-bearing titanium alloy (Ti-Cu) against Streptococcus mutans and Porphyromonas gingivalis. Sci. Rep. 2016, 6, 29985. [CrossRef] [PubMed]

144. Astasov-Frauenhoffer, M.; Koegel, S.; Waltimo, T.; Zimmermann, A.; Walker, C.; Hauser-Gerspach, I.; Jung, C. Antimicrobial efficacy of copper-doped titanium surfaces for dental implants. J. Mater. Sci. Mater. Med. 2019, 30, 84. [CrossRef] [PubMed]

145. Fowler, L.; Masia, N.; Cornish, L.A.; Chown, L.H.; Engqvist, H.; Norgren, S.; Öhman-Mägi, C.A.-O. Development of Antibacterial Ti-Cu(x) Alloys for Dental Applications: Effects of Ageing for Alloys with up to $10 \mathrm{wt} \% \mathrm{Cu}$. Materials 2019, 12, 4017. [CrossRef]

146. Li, K.; Xie, Y.; You, M.; Huang, L.; Zheng, X. Plasma sprayed cerium oxide coating inhibits H2O2-induced oxidative stress and supports cell viability. J. Mater. Sci. Mater. Med. 2016, 27, 100. [CrossRef] [PubMed]

147. Qi, S.; Wu, J.; Xu, Y.; Zhang, Y.; Wang, R.; Li, K.; Xu, Y. Chemical Stability and Antimicrobial Activity of Plasma-Sprayed Cerium Oxide-Incorporated Calcium Silicate Coating in Dental Implants. Implant Dent. 2019, 28, 564-570. [CrossRef] [PubMed]

148. Vassie, J.A.; Whitelock, J.M.; Lord, M.S. Endocytosis of cerium oxide nanoparticles and modulation of reactive oxygen species in human ovarian and colon cancer cells. Acta Biomater. 2017, 50, 127-141. [CrossRef] [PubMed]

149. Naganuma, T. Shape design of cerium oxide nanoparticles for enhancement of enzyme mimetic activity in therapeutic applications. Nano Res. 2016, 10, 199-217. [CrossRef]

150. Li, X.; Qi, M.; Sun, X.; Weir, M.D.; Tay, F.R.; Oates, T.W.; Dong, B.; Zhou, Y.; Wang, L.; Xu, H.H.K. Surface treatments on titanium implants via nanostructured ceria for antibacterial and anti-inflammatory capabilities. Acta Biomater. 2019, 94, 627-643. [CrossRef]

151. Levine, B.R.; Sporer, S.; Poggie, R.A.; Della Valle, C.J.; Jacobs, J.J. Experimental and clinical performance of porous tantalum in orthopedic surgery. Biomaterials 2006, 27, 4671-4681. [CrossRef] [PubMed]

152. Zhang, X.M.; Li, Y.; Gu, Y.X.; Zhang, C.N.; Lai, H.C.; Shi, J.Y. Ta-Coated Titanium Surface with Superior Bacteriostasis and Osseointegration. Int. J. Nanomed. 2019, 14, 8693-8706. [CrossRef] [PubMed] 
153. Xiang, Y.; Li, J.; Liu, X.; Cui, Z.; Yang, X.; Yeung, K.W.K.; Pan, H.; Wu, S. Construction of poly(lactic-co-glycolic acid)/ZnO nanorods/Ag nanoparticles hybrid coating on Ti implants for enhanced antibacterial activity and biocompatibility. Mater. Sci. Eng. C Mater. Biol. Appl. 2017, 79, 629-637. [CrossRef] [PubMed]

154. Vu, A.A.; Robertson, S.F.; Ke, D.; Bandyopadhyay, A.; Bose, S. Mechanical and biological properties of ZnO, $\mathrm{SiO}(2)$, and $\mathrm{Ag}(2) \mathrm{O}$ doped plasma sprayed hydroxyapatite coating for orthopaedic and dental applications. Acta Biomater. 2019, 92, 325-335. [CrossRef] [PubMed]

155. Li, Q.; Li, L.; Zhao, M.; Dong, L.; Wu, J.; Li, D. Biological actions of Cu/Zn coimplanted TiN on Ti-6Al-4V alloy. Biointerphases 2019, 14, 051008. [CrossRef] [PubMed]

156. Gao, Q.; Feng, T.; Huang, D.; Liu, P.; Lin, P.; Wu, Y.; Ye, Z.; Ji, J.; Li, P.; Huang, W. Antibacterial and hydroxyapatite-forming coating for biomedical implants based on polypeptide-functionalized titania nanospikes. Biomater. Sci. 2019, 8, 278-289. [CrossRef] [PubMed]

157. Costa, F.; Carvalho, I.F.; Montelaro, R.C.; Gomes, P.; Martins, M.C. Covalent immobilization of antimicrobial peptides (AMPs) onto biomaterial surfaces. Acta Biomater. 2011, 7, 1431-1440. [CrossRef]

158. Stallmann, H.P.; Faber, C.; Bronckers, A.L.; de Blieck-Hogervorst, J.M.; Brouwer, C.P.; Amerongen, A.V.; Wuisman, P.I. Histatin and lactoferrin derived peptides: Antimicrobial properties and effects on mammalian cells. Peptides 2005, 26, 2355-2359. [CrossRef]

159. Godoy-Gallardo, M.; Mas-Moruno, C.; Fernandez-Calderon, M.C.; Perez-Giraldo, C.; Manero, J.M.; Albericio, F.; Gil, F.J.; Rodriguez, D. Covalent immobilization of hLf1-11 peptide on a titanium surface reduces bacterial adhesion and biofilm formation. Acta Biomater. 2014, 10, 3522-3534. [CrossRef]

160. Godoy-Gallardo, M.; Mas-Moruno, C.; Yu, K.; Manero, J.M.; Gil Mur, F.J.; Kizhakkedathu, J.N.; Rodríguez, D. Antibacterial properties of hLf1-11 peptide onto titanium surfaces: A comparison study between silanization and surface initiated polymerization. Biomacromolecules 2015, 16, 483-496. [CrossRef]

161. Warnke, P.H.; Voss, E.; Russo, P.A.; Stephens, S.; Kleine, M.; Terheyden, H.; Liu, Q. Antimicrobial peptide coating of dental implants: Biocompatibility assessment of recombinant human beta defensin-2 for human cells. Int. J. Oral Maxillofac. Implants 2013, 28, 982-988. [CrossRef]

162. Gorr, S.U.; Abdolhosseini, M.; Shelar, A.; Sotsky, J. Dual host-defence functions of SPLUNC2/PSP and synthetic peptides derived from the protein. Biochem. Soc. Trans. 2011, 39, 1028-1032. [CrossRef] [PubMed]

163. Zhou, L.; Lai, Y.; Huang, W.; Huang, S.; Xu, Z.; Chen, J.; Wu, D. Biofunctionalization of microgroove titanium surfaces with an antimicrobial peptide to enhance their bactericidal activity and cytocompatibility. Colloids Surf. B Biointerfaces 2015, 128, 552-560. [CrossRef] [PubMed]

164. Holmberg, K.V.; Abdolhosseini, M.; Li, Y.; Chen, X.; Gorr, S.U.; Aparicio, C. Bio-inspired stable antimicrobial peptide coatings for dental applications. Acta Biomater. 2013, 9, 8224-8231. [CrossRef] [PubMed]

165. Chen, X.; Hirt, H.; Li, Y.; Gorr, S.U.; Aparicio, C. Antimicrobial GL13K peptide coatings killed and ruptured the wall of Streptococcus gordonii and prevented formation and growth of biofilms. PLoS ONE 2014, 9, e111579. [CrossRef] [PubMed]

166. Li, J.Y.; Wang, X.J.; Wang, L.N.; Ying, X.X.; Ren, X.; Liu, H.Y.; Xu, L.; Ma, G.W. High in vitro antibacterial activity of Pac-525 against Porphyromonas gingivalis biofilms cultured on titanium. Biomed Res. Int. 2015, 2015, 909870. [CrossRef]

167. He, Y.; Zhang, Y.; Shen, X.; Tao, B.; Liu, J.; Yuan, Z.; Cai, K. The fabrication and in vitro properties of antibacterial polydopamine-LL-37-POPC coatings on micro-arc oxidized titanium. Colloids Surf. B Biointerfaces 2018, 170, 54-63. [CrossRef] [PubMed]

168. Wei, S.; Zhou, L.; Deng, Y.; Chen, X.; Xiong, X.; Deng, F.; Wei, S. A carboxymethyl chitosan and peptide-decorated polyetheretherketone ternary biocomposite with enhanced antibacterial activity and osseointegration as orthopedic/dental implants. J. Mater. Chem. B 2016, 4, 1878-1890. [CrossRef]

169. Campos, D.M.; Toury, B.; D'Almeida, M.; Attik, G.N.; Ferrand, A.; Renoud, P.; Grosgogeat, B. Acidic pH resistance of grafted chitosan on dental implant. Odontology 2015, 103, 210-217. [CrossRef]

170. Palla-Rubio, B.; Araújo-Gomes, N.; Fernández-Gutiérrez, M.; Rojo, L.; Suay, J.; Gurruchaga, M.; Goñi, I. Synthesis and characterization of silica-chitosan hybrid materials as antibacterial coatings for titanium implants. Carbohydr. Polym. 2019, 203, 331-341. [CrossRef]

171. Valverde, A.; Perez-Alvarez, L.; Ruiz-Rubio, L.; Pacha Olivenza, M.A.; Garcia Blanco, M.B.; Diaz-Fuentes, M.; Vilas-Vilela, J.L. Antibacterial hyaluronic acid/chitosan multilayers onto smooth and micropatterned titanium surfaces. Carbohydr. Polym. 2019, 207, 824-833. [CrossRef] [PubMed] 
172. Divakar, D.D.; Jastaniyah, N.T.; Altamimi, H.G.; Alnakhli, Y.O.; Muzaheed; Alkheraif, A.A.; Haleem, S. Enhanced antimicrobial activity of naturally derived bioactive molecule chitosan conjugated silver nanoparticle against dental implant pathogens. Int. J. Biol. Macromol. 2018, 108, 790-797. [CrossRef] [PubMed]

173. Li, W.; Yang, Y.; Zhang, H.; Xu, Z.; Zhao, L.; Wang, J.; Qiu, Y.; Liu, B. Improvements on biological and antimicrobial properties of titanium modified by AgNPs-loaded chitosan-heparin polyelectrolyte multilayers. J. Mater. Sci. Mater. Med. 2019, 30, 52. [CrossRef] [PubMed]

174. Norowski, P.A.; Courtney, H.S.; Babu, J.; Haggard, W.O.; Bumgardner, J.D. Chitosan coatings deliver antimicrobials from titanium implants: A preliminary study. Implant Dent. 2011, 20, 56-67. [CrossRef] [PubMed]

Publisher's Note: MDPI stays neutral with regard to jurisdictional claims in published maps and institutional affiliations.

(C) 2020 by the authors. Licensee MDPI, Basel, Switzerland. This article is an open access article distributed under the terms and conditions of the Creative Commons Attribution (CC BY) license (http://creativecommons.org/licenses/by/4.0/). 